\title{
Sodium-Bicarbonate Cotransport in Retinal Müller (Glial) Cells of the Salamander
}

\author{
Eric A. Newman \\ Department of Physiology, University of Minnesota, Minneapolis, Minnesota 55455
}

\begin{abstract}
An electrogenic $\mathrm{Na}^{+} / \mathrm{HCO}_{3}^{-}$cotransport system was studied in freshly dissociated Müller cells of the salamander retina. Cotransporter currents were recorded from isolated cells using the whole-cell, voltage-clamp technique following the block of $\mathrm{K}^{+}$. conductance with external $\mathrm{Ba}^{2+}$ and internal $\mathrm{Cs}^{+}$. At constant $\mathrm{pH}_{\mathrm{o}}$, an outward current was evoked when extracellular $\mathrm{HCO}_{3}^{-}$concentration was raised by pressure ejecting a $\mathrm{HCO}_{3}^{-}-$buffered solution onto the surface of cells bathed in nominally $\mathrm{HCO}_{3}^{-}$-free solution. The $\mathrm{HCO}_{3}^{-}$-evoked outward current was reduced to $4.4 \%$ of control by $0.5 \mathrm{~mm}$ DIDS $\left(4,4^{\prime}\right.$ diisothiocyanatostilbene-2,2'-disulfonate), to $28.8 \%$ of control by 2 mm DNDS (4,4'-dinitrostilbene-2,2' -disulfonate), and to $28.4 \%$ of control by $2 \mathrm{~mm}$ harmaline. Substitution of choline for $\mathrm{Na}^{+}$in bath and ejection solutions reduced the response to $1.3 \%$ of control. Bicarbonate-evoked currents of normal magnitude were recorded when methane sulfonate was substituted for $\mathrm{Cl}^{-}$in bath, ejection, and intracellular solutions.

Similarly, an outward current was evoked when extracelIular $\mathrm{Na}^{+}$concentration was raised in the presence of $\mathrm{HCO}_{3}^{-}$. The $\mathrm{Na}^{+}$-evoked response was reduced to $16.2 \%$ of control by $2 \mathrm{~mm}$ DNDS and was abolished by removal of $\mathrm{HCO}_{3}^{-}$from bath and ejection solutions. Taken together, these results (block by stilbenes and harmaline, $\mathrm{HCO}_{3}^{-}$and $\mathrm{Na}^{+}$ dependence, $\mathrm{Cl}^{-}$independence) indicate that salamander Müller cells possess an electrogenic $\mathrm{Na}^{+} / \mathrm{HCO}_{3}^{-}$cotransport system.
\end{abstract}

$\mathrm{Na}^{+} / \mathrm{HCO}_{3}^{-}$cotransporter sites were localized primarily at the endfoot region of Müller cells. Ejection of $\mathrm{HCO}_{3}^{-}$onto the endfoot evoked outward currents 10 times larger than currents evoked by ejections onto the opposite (distal) end of the cell. The reversal potential of the cotransporter was determined by DNDS block of cotransport current. In the absence of a transmembrane $\mathrm{HCO}_{3}^{-}$gradient, the reversal potential varied systematically as a function of the transmembrane $\mathrm{Na}^{+}$gradient. The reversal potential was -0.1 $\mathrm{mV}$ for a $\left[\mathrm{Na}^{+}\right]_{0}:\left[\mathrm{Na}^{+}\right]_{\text {, }}$ ratio of $1: 1$ and $-25.2 \mathrm{mV}$ for a $\mathrm{Na}^{+}$ gradient ratio of 7.4:1. Based on these values, the estimated stoichiometry of the cotransporter was $2.80 \pm 0.13: 1$ $\left(\mathrm{HCO}_{3}^{-}: \mathrm{Na}^{+}\right)$. Possible functions of the glial cell $\mathrm{Na}^{+} / \mathrm{HCO}_{3}^{-}$

Received Mar. 4, 1991; revised June 21, 1991; accepted July 31, 1991

I thank Paul W. Ceelen for his excellent technical assistance, and Janice I. Gepner and David G. Levitt for their helpful comments on the manuscript. This work was supported by National Institutes of Health Grant EY 04077

Correspondence should be addressed to Eric A. Newman, Department of Physiology, University of Minnesota, 6-255 Millard Hall, 435 Delaware Street S.E., Minneapolis, MN 55455.

Copyright (C) 1991 Society for Neuroscience $0270-6474 / 91 / 113972-12 \$ 05.00 / 0$ cotransporter, including the regulation of $\mathrm{CO}_{2}$ in the retina and the regulation of cerebral blood flow, are discussed.

Neuronal activity within the CNS leads to changes in the extracellular concentration of several ion species, including $\mathrm{K}^{+}$ (Nicholson et al., 1978; Nicholson, 1980), $\mathrm{H}^{+}$(Urbanics et al., 1978; Sykova and Svoboda, 1990), and $\mathrm{Ca}^{2+}$ (Nicholson et al., 1978). These ion variations must be regulated in order to maintain normal neuronal function. It is believed that glial cells play an important role in the regulation of at least one of these ions, $\mathrm{K}^{+}$(Gardner-Medwin, 1983; Cserr, 1986). Evidence for this function is particularly compelling in the vertebrate retina where the Müller cell, the principal retinal glial cell (Newman, 1988), has been shown to regulate light-evoked variations in $\left[\mathrm{K}^{+}\right]_{\mathrm{o}}$ (Newman et al., 1984; Karwoski et al., 1989).

Glial cells may also contribute to $\mathrm{CO}_{2}$ and $\mathrm{pH}$ regulation in the CNS. This function is suggested by the localization of the enzyme carbonic anhydrase, which catalyzes the hydrolysis of $\mathrm{CO}_{2}$ to $\mathrm{HCO}_{3}^{-}$(Maren, 1967), to glial cells in the brain (Langley et al., 1980). A glial cell role in $\mathrm{pH}$ homeostasis is also suggested by the recent demonstration that an electrogenic $\mathrm{Na}^{+} / \mathrm{HCO}_{3}^{-}$ cotransport system is present in a number of glial (or glial-like) cells of the nervous system, including amphibian optic nerve astrocytes (Astion and Orkand, 1988; Astion et al., 1989b), amphibian retinal pigment epithelium cells (Hughes et al., 1989), and leech glial cells (Deitmer and Schlue, 1989; Deitmer and Szatkowski, 1990).

The electrogenic $\mathrm{Na}^{+} / \mathrm{HCO}_{3}^{-}$cotransport system was first described by Boron and Boulpaep (1983) in the proximal tubule of the kidney, where it is believed to play an instrumental role in the resorption of $\mathrm{HCO}_{3}^{-}$from the tubule lumen to the blood (Boron and Boulpaep, 1989). The cotransporter has been described in corneal endothelial cells (Wiederholt et al., 1985) and in ciliary epithelial cells (Helbig et al., 1989). In these tissues, it is thought to participate in fluid transport. The cotransporter has also been identified in gastric oxynic cells (Curci et al., 1987) and smooth muscle cells (Brading and Aickin, 1990).

The cotransporter is believed to transport two or three $\mathrm{HCO}_{3}^{-}$ions, or equivalent ion species, along with one $\mathrm{Na}^{+}$across the plasma membrane (Soleimani et al., 1987; Hughes et al., 1989). Because more $\mathrm{HCO}_{3}^{-}$ions are transported than are $\mathrm{Na}^{+}$ ions, a net negative charge accompanies the $\mathrm{Na}^{+} / \mathrm{HCO}_{3}^{-}$flux. This electrogenic aspect of the $\mathrm{Na}^{+} / \mathrm{HCO}_{3}^{-}$cotransporter distinguishes it from several other acid/base transport systems, including the $\mathrm{Na}^{+} / \mathrm{H}^{+}$exchanger, the $\mathrm{Cl}^{-} / \mathrm{HCO}_{3}^{-}$exchanger, and the $\mathrm{Na}^{+}$-dependent $\mathrm{Cl}^{-} / \mathrm{HCO}_{3}^{-}$exchanger, all of which are electroneutral.

To date, cotransporter function in the neural retina has not been investigated. In the present study, I have approached this 
question by examining the properties of the cotransport system in retinal Müller cells. The voltage-clamp technique has been used to measure cotransporter currents in single dissociated Müller cells, the first such measurements to be made in single cells of any system. This technique has also permitted the determination of cotransporter stoichiometry and the measurement of cotransporter distribution over the surface of single cells.

A preliminary report of some of these findings has appeared previously (Newman and Astion, 1991).

\section{Materials and Methods}

Animals. Tiger salamanders (Ambystoma tigrinum, aquatic stage) were used. Animals were killed by decapitation and pithing.

Cell dissociation. The cell dissociation procedure has been described previously (Newman, 1985a) and yields cells whose membrane properties are similar to those of in situ cells. Briefly, isolated retinas from hemisected eyes were incubated in $\mathrm{Ca}^{2+}-\mathrm{Mg}^{2+}$-free Ringer's solution containing papain ( 20 units of activity $/ 3 \mathrm{ml}$ ) and cysteine $(2 \mathrm{~mm})$. The tissue was incubated for $20-30$ min at $22^{\circ} \mathrm{C}$ while being triturated gently at $5 \mathrm{~min}$ intervals. The tissue was then rinsed twice in normal Ringer's containing 1\% BSA and twice more in Ringer's containing 1\% BSA and $0.1 \%$ DNAase. The tissue was maintained in the final rinse solution at $0{ }^{\circ} \mathrm{C}$ for a period of $3-6 \mathrm{hr}$ and was then triturated using a series of Pasteur pipettes with progressively smaller tip openings. Dissociated cells were placed in a perfusion chamber and settled onto a glass slide coated with concanavalin $A$. The perfusion chamber had a volume of $\sim 0.25 \mathrm{ml}$ and was perfused at a rate of $\sim 1.5 \mathrm{ml} / \mathrm{min}$.

Cell recording. Individual dissociated cells were whole-cell voltage clamped (Hamill et al., 1981) using single suction electrodes attached to the cell soma (except as noted below). Records were low-pass filtered at $200 \mathrm{~Hz}(20 \mathrm{~Hz}$ for reversal potential determinations). Cells were maintained at $15-17^{\circ} \mathrm{C}$ in the perfusion chamber. Recordings were made from cells within $2 \mathrm{hr}$ of dissociation.

Fur reversal potential determinations, it was essential that cells be completely perfused with the intracellular solution. Internal perfusion was facilitated by patching onto the cell endfoot, where the cotransporter currents were monitored. In addition, within $90 \mathrm{sec}$ after whole-cell recording was achieved, fluid from the recording pipette was gently pressure ejected into the cell endfoot region, bulging out the endfoot slightly. Control experiments demonstrated that patching onto the endfoot and ejecting moderate amounts of fluid into the cell did not modify $\mathrm{Na}^{+} / \mathrm{HCO}_{3}^{-}$cotransporter currents. Determination of the reversal potential for each cell was not begun until at least $6 \mathrm{~min}$ after whole-cell recording was achieved.

Liquid junction potential. Due to the different ionic composition of recording pipette and bath solutions, a liquid junction potential was generated. The error introduced by the junction potential was corrected in reversal potential experiments by subtracting the junction potential $(+3.5 \mathrm{mV})$ from measured cell potentials. The junction potential was determined by measuring the change in the patch pipette potential as it was bathed alternately in intracellular solution (Table 1, no. 17) and bath solution (no. 15). A $3 \mathrm{M} \mathrm{KCl} /$ agarose bridge served as the reference electrode in junction potential determinations.

Fluid ejection. Test solutions were pressure ejected onto the surface of dissociated Müller cells through extracellular pipettes. Ejection pipettes had an inside tip diameter of $1-2 \mu \mathrm{m}$ and were generally positioned within $15 \mu \mathrm{m}$ of the cell surface (within $2 \mu \mathrm{m}$ in localization experiments). Ejection durations were brief $(6-50 \mathrm{msec})$, and only a small region of the cell surface was exposed to the test solution.

In some cases, double-barreled ejection pipettes were used to eject two test solutions sequentially onto a single cell. The following control experiment was performed to determine whether the two barrels of these pipettes delivered equal fluid ejections.

Müller cells were bathed in HEPES-buffered solution (no. 1) while a $\mathrm{HCO}_{3}^{-}$-buffered solution (no. 2) was ejected onto the cell surface. Both barrels of double-barreled pipettes contained identical $\mathrm{HCO}_{3}^{-}$-buffered solution. Cell responses to ejections from the two barrels proved to be almost identical. For each of three pipettes tested, the average responses produced by ejections from the two barrels differed by less than $2 \%$. When the results of the three pipettes were averaged, the responses evoked by the two barrels proved to be within $1 \%$ of each other.
Ejection protocol. In several experiments, the Müller cell $\mathrm{Na}^{+} /$ $\mathrm{HCO}_{3}^{-}$cotransporter was characterized by ejecting a $\mathrm{HCO}_{3}^{-}$-buffered solution onto cells bathed in a nominally $\mathrm{HCO}_{3}^{-}$-free perfusion solution. These ejections evoked a characteristic cotransporter current. Doublebarreled ejection pipettes were used when testing the effects of a pharmacological agent or ion substitution on this cotransporter response.

The protocol for such double-barreled ejection experiments was as follows. (1) A whole-cell, voltage-clamp recording was attained from a Müller cell bathed in HEPES-buffered bath solution. (2) $\mathrm{A} \mathrm{HCO}_{3}^{-}$-buffered solution was pressure ejected onto the cell from one barrel of a double-barreled pipette. (3) The bath was switched to a HEPES-buffered solution containing the pharmacological agent. Pretreatment with this solution generally lasted 1-2 min. (4) $\mathrm{A} \mathrm{HCO}_{3}^{-}$-buffered solution containing the identical concentration of the agent was pressure ejected from the second barrel of the pipette. (5) Recovery was assessed by switching back to the control bath solution and ejecting control $\mathrm{HCO}_{3}^{-}$solution from the first barrel of the ejection pipette.

Measurement of responses. Whole-cell, voltage-clamp currents were recorded and stored digitally using a digital oscilloscope and an ATcompatible computer. Response area, rather than response amplitude, was used as a measure of current magnitude. An area measurement (current $\times$ time) corresponds to the total charge transferred across the cell membrane during the period of measurement. Area measurement was used because it was found to minimize errors due to several factors, including (1) transients not related to cotransport current [e.g., the 4,4'dinitrostilbene-2,2'-disulfonate (DNDS) transient; see Fig. 12], (2) variations in the time course of responses (which depended on the precise geometry between the ejection pipette and the cell), and (3) signal noise (which was large since response currents were very small).

Solutions. Composition of the solutions used is given in Table 1. In pharmacological studies, drugs were added directly to bath and ejection solutions. In $\mathrm{Na}^{+}$-free studies, choline or $N$-methyl-D-glucamine was substituted for $\mathrm{Na}^{+}$. In $\mathrm{Cl}^{-}$-free studies, methane sulfonate was substituted for $\mathrm{Cl}^{-}$. DNDS was obtained from Pfaltz and Bauer (Waterbury, $\mathrm{CT}$ ). All other drugs were obtained from Sigma (St. Louis, MO).

\section{Results}

Response to increased $\left[\mathrm{HCO}_{3}^{-}\right]$。

The electrogenic $\mathrm{Na}^{+} / \mathrm{HCO}_{3}^{-}$cotransporter was characterized by monitoring the electrical responses of dissociated Müller cells to changes in extracellular $\mathrm{HCO}_{3}^{-}$concentration, $\left[\mathrm{HCO}_{3}^{-}\right]_{0}$. For most experiments reported here, cells were bathed in a HEPESbuffered solution (Table 1 , no. 1) that was nominally $\mathrm{HCO}_{3}^{-}$ free. This bath solution contained $5 \mathrm{mM} \mathrm{Ba}^{2+}$, which effectively blocked the large $\mathrm{K}^{+}$conductance of the cell. The recording pipette (intracellular) solution (no. 7) was also HEPES buffered and nominally $\mathrm{HCO}_{3}$ free and contained a low concentration of $\mathrm{Na}^{+}(\sim 5 \mathrm{~mm})$, so that a large inward $\mathrm{Na}^{+}$gradient was present across the cell membrane. The intracellular solution contained $98 \mathrm{~mm} \mathrm{Cs}^{+}$, which further blocked cell $\mathrm{K}^{+}$conductance.

The resting potential of dissociated Müller cells under physiological conditions is $\sim-89 \mathrm{mV}$ (Newman, 1987). In the presence of external $\mathrm{Ba}^{2+}$ and internal $\mathrm{Cs}^{+}$, the resting potential was reduced to near $0 \mathrm{mV}$. These $\mathrm{K}^{+}$channel blockers increased the cell input resistance from a control value of $9.7 \mathrm{M} \Omega$ (Newman, 1987 ) to $412 \pm 47 \mathrm{M} \Omega$ (mean $\pm \mathrm{SEM} ; n=27$ ). Under voltage clamp, residual $\mathrm{K}^{+}$current was less than $2 \mathrm{pA}$ when cells were held at a potential within a few millivolts of the cell resting potential.

The $\mathrm{Na}^{+} / \mathrm{HCO}_{3}^{-}$cotransporter was activated by pressure ejecting a $\mathrm{HCO}_{3}^{-}$-buffered solution (no. 2) from a pipette onto the cell surface. The ejection raised $\left[\mathrm{HCO}_{3}^{-}\right]_{0}$ from a value near 0 ImM to a maximum of 26 mm over a small region of the cell surface.

Focal ejection of $\mathrm{HCO}_{3}^{-}$produced a transient hyperpolarization in Müller cells when cells were current clamped (Fig. 1, voltage). This hyperpolarization is generated by an influx of $\mathrm{HCO}_{3}^{-}$into the cell. The influx of negative charge should be 


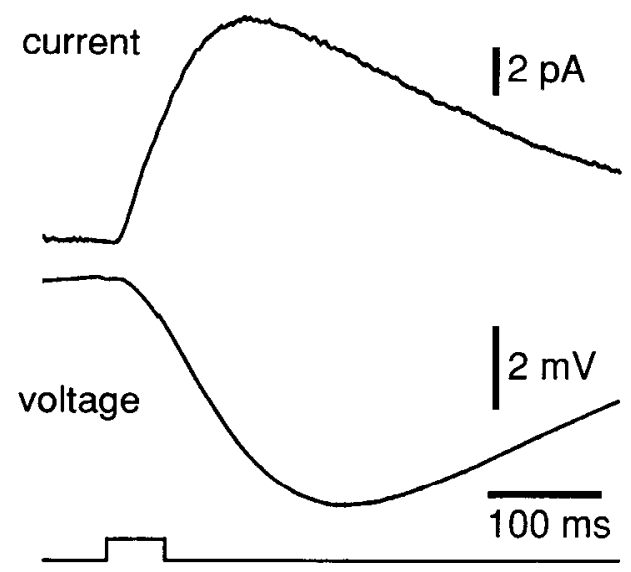

Figure 1. Responses of a dissociated salamander Müller cell to increased $\left[\mathrm{HCO}_{3}^{-}\right]_{0}$. The cell was bathed in a HEPES-buffered, nominally $\mathrm{HCO}_{3}^{-}$-free solution (Table 1, no. 1). $\mathrm{A} \mathrm{HCO}_{3}^{-}$-buffered solution (no. 2) was then pressure ejected onto the cell endfoot. When the cell was voltage clamped, $\mathrm{HCO}_{3}^{-}$ejection evoked an outward current (current). When the same cell was current clamped, an identical ejection evoked a cell hyperpolarization (voltage). Voltage-clamp holding potential, $0 \mathrm{mV}$. Cell membrane potential under current clamp, $-4 \mathrm{mV}$. In Figures 112 , the bottom trace indicates the time course of the ejection pressure pulse. Traces illustrated in Figures 1-12 are averages of 8-25 sweeps. recorded as an outward current when cells are voltage clamped. This proved to be the case. When Müller cells were whole-cell voltage clamped, ejection of $\mathrm{HCO}_{3}^{-}$onto the cell surface produced an outward current (Fig. 1, current).

As seen in Figure 1, Müller cell responses to $\mathrm{HCO}_{3}^{-}$ejection (both voltage and current) were relatively prolonged, far outlasting the pressure pulse. In addition, the voltage response had a somewhat slower time course than did the current response. This discrepancy arises because the cell membrane (which has a time constant of several hundred milliseconds when its $\mathrm{K}^{+}$ channels are blocked) acts as a leaky integrator with a very slow time constant.

The voltage-clamp technique offered several advantages over simply monitoring cell membrane potential when characterizing cell $\mathrm{HCO}_{3}^{-}$responses. As illustrated in Figure 1, voltage-clamp measurements reflect the time course of $\mathrm{HCO}_{3}^{-}$flux more accurately than do current-clamp records. In addition, nonohmic properties of the cell membrane (Newman, 1985b) will not confound results under voltage clamp. Finally, the reversal potential of the response is far easier to determine under voltage clamp. For these reasons, voltage-clamp measurements were used exclusively in characterizing the $\mathrm{Na}^{+} / \mathrm{HCO}_{3}^{-}$cotransporter in this study.

\section{Table 1. Composition of solutions}

$\mathrm{Cl}^{-}$-containing solutions

\begin{tabular}{|c|c|c|c|c|c|c|c|c|c|c|c|c|c|c|c|}
\hline No. Solution name & $\mathrm{NaCl}$ & $\begin{array}{l}\text { Choline } \\
\mathrm{Cl}\end{array}$ & $\mathbf{K C l}$ & $\mathrm{CaCl}_{2}$ & $\mathrm{MgCl}_{2}$ & $\mathrm{BaCl}_{2}$ & $\mathrm{CsCl}$ & $\begin{array}{l}\text { Dex- } \\
\text { trose }\end{array}$ & $\begin{array}{l}\mathrm{Na}- \\
\mathrm{HCO}_{3}\end{array}$ & $\begin{array}{l}\text { Choline } \\
\mathrm{HCO}_{3}\end{array}$ & HEPES & $\mathrm{NaOH}$ & $\begin{array}{l}N \text {-methyl- } \\
\text { D-gluc- } \\
\text { amine }\end{array}$ & $\begin{array}{l}\% \mathrm{CO}_{2} \\
\text { in } \mathrm{O}_{2}\end{array}$ & $\mathrm{pH}$ \\
\hline 1 HEPES & 98.5 & & 2.5 & 1.8 & 0.8 & 5 & & 10 & & & 10 & $\sim 5$ & & 0 & 7.5 \\
\hline $2 \mathrm{HEPES} / \mathrm{HCO}_{3}^{-}$ & 72.5 & & 2.5 & 1.8 & 0.8 & 5 & & 10 & 26 & & 10 & $\sim 5$ & & 5 & 7.5 \\
\hline $30 \mathrm{Na}^{+} / \mathrm{HEPES}$ & & 98.5 & 2.5 & 1.8 & 0.8 & 5 & & 10 & & & 10 & & $\sim 5$ & 0 & 7.5 \\
\hline $40 \mathrm{Na}^{+} / \mathrm{HEPES} / \mathrm{HCO}_{3}^{-}$ & & 72.5 & 2.5 & 1.8 & 0.8 & 5 & & 10 & & 26 & 10 & & $\sim 5$ & 5 & 7.5 \\
\hline 5 Low $\mathrm{HCO}_{3}^{-}$ & 104 & & 2.5 & 1.8 & 0.8 & 5 & & 10 & 2 & & & & & 5 & 6.4 \\
\hline $6 \mathrm{High} \mathrm{HCO}_{3}^{-}$ & 80 & & 2.5 & 1.8 & 0.8 & 5 & & 10 & 26 & & & & & 5 & 7.5 \\
\hline 7 Intracellular & & & & & & & 98 & & & & 10 & $\sim 5$ & & & 7.1 \\
\hline $80 \mathrm{Na}^{+}$intracellular & & & & & & & 98 & & & & 10 & & $\sim 5$ & & 7.1 \\
\hline $9 \mathrm{KCl}$ intracellular & & & 98 & & & & & & & & 10 & $\sim 5$ & & & 7.1 \\
\hline $\begin{aligned} 100 & \mathrm{Na}^{+} \text {HEPES/HCO } \\
& \text { intracellular }\end{aligned}$ & & & & & & & 87 & & & 11 & 10 & & $\sim 5$ & 5 & 7.1 \\
\hline $\mathrm{Cl}^{-}$-free solutions & & & & & & & & & & & & & & & \\
\hline
\end{tabular}

\begin{tabular}{|c|c|c|c|c|c|c|c|c|c|c|c|c|c|c|c|c|}
\hline No. Solution name & NaMeS & $\begin{array}{l}\text { Choline } \\
\text { MeS }\end{array}$ & KMeS & $\begin{array}{l}\mathrm{Ca}- \\
\mathrm{MeS}\end{array}$ & $\begin{array}{l}\text { Mg- } \\
\text { MeS }\end{array}$ & $\begin{array}{l}\text { Ba- } \\
\text { MeS }\end{array}$ & $\begin{array}{l}\text { Cs- } \\
\text { MeS }\end{array}$ & $\begin{array}{l}\text { Dex- } \\
\text { trose }\end{array}$ & $\begin{array}{l}\mathrm{Na}- \\
\mathrm{HCO}_{3}\end{array}$ & $\begin{array}{l}\text { Choline } \\
\mathrm{HCO}_{3}^{-} \\
\end{array}$ & HEPES & $\mathrm{NaOH}$ & $\begin{array}{l}N \text {-methyl- } \\
\text { D-gluc- } \\
\text { amine }\end{array}$ & $\mathrm{CsOH}$ & $\begin{array}{l}\% \mathrm{CO}_{2} \\
\text { in } \mathrm{O}_{2} \\
\end{array}$ & $\mathbf{p H}$ \\
\hline 11 HEPES & 98.5 & & 2.5 & 1.8 & 0.8 & 5 & & 10 & & & 10 & $\sim 5$ & & & 0 & 7.5 \\
\hline $12 \mathrm{HEPES} / \mathrm{HCO}_{3}^{-}$ & 72.5 & & 2.5 & 1.8 & 0.8 & 5 & & 10 & 26 & & 10 & $\sim 5$ & & & 5 & 7.5 \\
\hline $1326 \mathrm{Na}^{+}$ & & 65 & & 1.8 & 0.8 & 20 & & & 26 & & 10 & & $\sim 5$ & & 5 & 7.5 \\
\hline $1448 \mathrm{Na}^{+}$ & 17 & 48 & & 1.8 & 0.8 & 20 & & & 26 & & 10 & $\sim 5$ & & & 5 & 7.5 \\
\hline $1596 \mathrm{Na}^{+}$ & 65 & & & 1.8 & 0.8 & 20 & & & 26 & & 10 & $\sim 5$ & & & 5 & 7.5 \\
\hline 16 Intracellular & & & & & & & 98 & & & & 10 & $\sim 5$ & & & & 7.1 \\
\hline $1726 \mathrm{Na}^{+}$intracellular & & & & & & & & & 26 & & 106 & & & -53 & 5 & 7.5 \\
\hline $1813 \mathrm{Na}^{+}$intracellular & & & & & & & & & 13 & 13 & 106 & & & $\sim 53$ & 5 & 7.5 \\
\hline
\end{tabular}

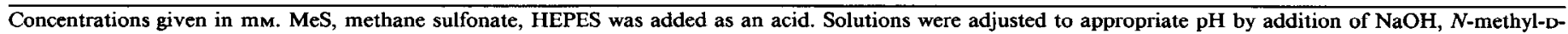
glucamine, or $\mathrm{CsOH}$ after bubbling. Where $\% \mathrm{CO}_{2}$ is not specified, solutions were not bubbled. 


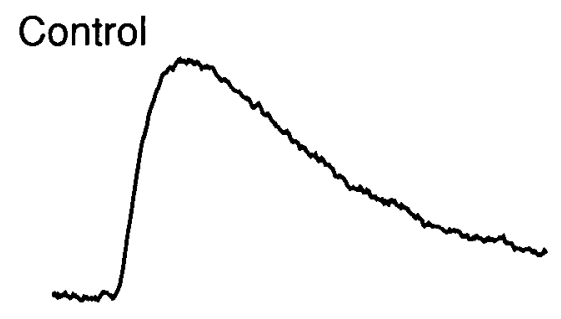

\section{$0.5 \mathrm{mM}$ DIDS}

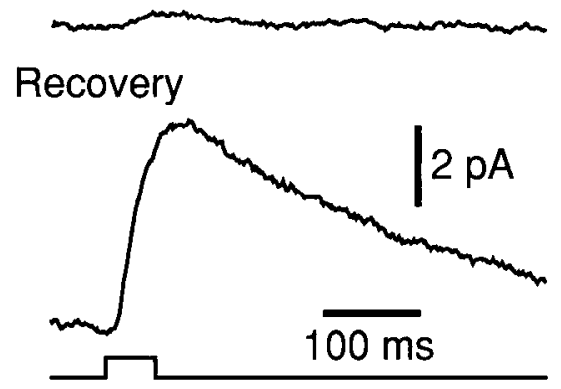

Figure 2. DIDS block of $\mathrm{HCO}_{3}^{-}$response. DIDS ( $\left.0.5 \mathrm{~mm}\right)$, a stilbene blocker of $\mathrm{Na}^{+} / \mathrm{HCO}_{3}^{-}$cotransport, almost completely inhibited the outward current evoked by $\mathrm{HCO}_{3}^{-}$ejection. Seven minutes following washout of DIDS, the response recovered to $83 \%$ of its control magnitude. (Substantially less recovery was observed in most trials.) In Figures 27, double-barreled ejection pipettes were used to eject a control solution from one barrel, and a solution with drug added (or ion substitute), from the second barrel. See Materials and Methods for details. Holding potential, $0 \mathrm{mV}$.

\section{Pharmacology of $\mathrm{HCO}_{3}^{-}$response}

The outward current evoked by $\mathrm{HCO}_{3}^{-}$ejections was most likely generated by one of two mechanisms. Either $\mathrm{HCO}_{3}^{-}$entered the cell through a $\mathrm{HCO}_{3}^{-}$-permeable anion channel, or it was transported into the cell via an electrogenic process, for example, an $\mathrm{Na}^{+} / \mathrm{HCO}_{3}^{-}$cotransport system. A series of pharmacological and ion substitution experiments was conducted to differentiate between these two possibilities.
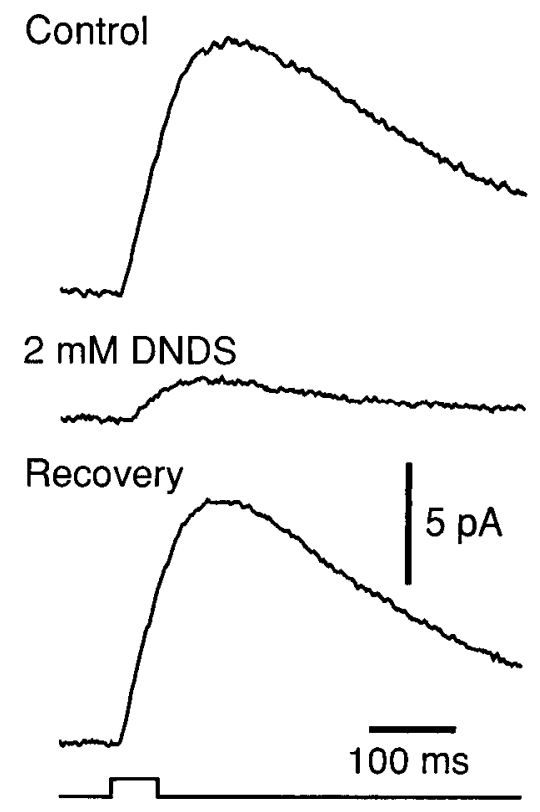

Figure 3. DNDS block of $\mathrm{HCO}_{3}^{-}$response. DNDS (2 mm) a stilbene, partially blocked the $\mathrm{HCO}_{3}^{-}$response. Recovery of the response following washout was rapid and complete. Holding potential, $0 \mathrm{mV}$.

Several disulfonic stilbenes, including DIDS (4,4'-diisothiocyanatostilbene-2,2'-disulfonic acid), SITS (4-acetamido-4'-isothiocyanatostilbene-2,2'-disulfonic acid), and DNDS, have been shown to block the $\mathrm{Na}^{+} / \mathrm{HCO}_{3}^{-}$cotransporter in millimolar concentrations in other systems (Boron and Boulpaep, 1989). The effect of two of these stilbenes, DIDS and DNDS, on Müller cells was assessed using the double-barreled $\mathrm{HCO}_{3}^{-}$-ejection protocol described in Materials and Methods.

DIDS proved extremely effective in blocking the outward current evoked by $\mathrm{HCO}_{3}^{-}$ejection (Fig. 2). DIDS at $0.5 \mathrm{~mm}$ reduced the $\mathrm{HCO}_{3}^{-}$response to $4.4 \%$ of its control magnitude

Table 2. Inhibition of $\mathrm{Na}^{+} / \mathrm{HCO}_{3}^{-}$cotransport current

\begin{tabular}{|c|c|c|c|c|c|}
\hline \multirow[b]{2}{*}{ Test condition } & \multirow[b]{2}{*}{$\begin{array}{l}\text { Conc. } \\
\text { (mM) }\end{array}$} & \multirow[b]{2}{*}{$n$} & \multicolumn{3}{|c|}{$\underline{\text { Response magnitude }}$} \\
\hline & & & Control (pC) & Test ( $\%$ control) & $\begin{array}{l}\text { Recovery } \\
\text { (\% control) }\end{array}$ \\
\hline \multicolumn{6}{|l|}{$\mathrm{HCO}_{3}^{-}$ejection } \\
\hline DIDS & 0.5 & 11 & $1.72 \pm 0.31$ & $4.4 \pm 1.0$ & $57.3 \pm 4.3$ \\
\hline DNDS & 2.0 & 23 & $1.86 \pm 0.16$ & $28.8 \pm 1.6$ & $103.8 \pm 3.0$ \\
\hline Harmaline & 2 & 8 & $1.26 \pm 0.08$ & $28.4 \pm 4.6$ & $103.0 \pm 8.0$ \\
\hline Amiloride & 1 & 8 & $2.07 \pm 0.27$ & $94.0 \pm 7.4$ & $111.7 \pm 4.6$ \\
\hline Ouabain & 0.01 & 8 & $2.64 \pm 0.24$ & $91.2 \pm 7.7$ & $99.8 \pm 2.1$ \\
\hline $\mathrm{Na}^{+}$free & & 18 & $1.68 \pm 0.23$ & $1.3 \pm 0.7$ & $101.4 \pm 3.7$ \\
\hline $\mathrm{Cl}^{-}$free & & $-{ }^{a}$ & $1.30 \pm 0.09$ & $97.7 \pm 10.0$ & \\
\hline \multicolumn{6}{|l|}{$\mathrm{Na}^{+}$ejection } \\
\hline DNDS & 2.0 & 14 & $1.32 \pm 0.16$ & $16.2 \pm 2.0$ & $97.2 \pm 2.8$ \\
\hline $\mathrm{HCO}_{3}^{-}$free & & 16 & $0.94 \pm 0.10$ & $-1.8 \pm 2.3^{b}$ & $101.6 \pm 3.5$ \\
\hline
\end{tabular}

Values given as mean \pm SEM. Responses were evoked by raising $\left[\mathrm{HCO}_{3}^{-}\right]_{\mathrm{o}}$ or $\left[\mathrm{Na}^{+}\right]_{0}$ at the endfeet of Müller cells. Response magnitude measured as the area of the response (units: pC; time $\times$ current) for a $450 \mathrm{msec}$ period following stimulus onset. Recovery was measured at $\sim 2$ min following drug washout except for DIDS, which was measured at $\sim 7$ min.

a In the $\mathrm{Cl}^{-}$-free experiment, control responses and $0 \mathrm{~mm} \mathrm{Cl}^{-}$responses were measured in two separate sets of cells using a matched group of ejection pipettes; $n=25$ for control cells, and $n=11$ for test cells.

${ }^{o}$ In $\mathrm{HCO}_{3}^{-}$-free solutions, $\mathrm{Na}^{+}$ejection evoked a small inward (negative) current. 


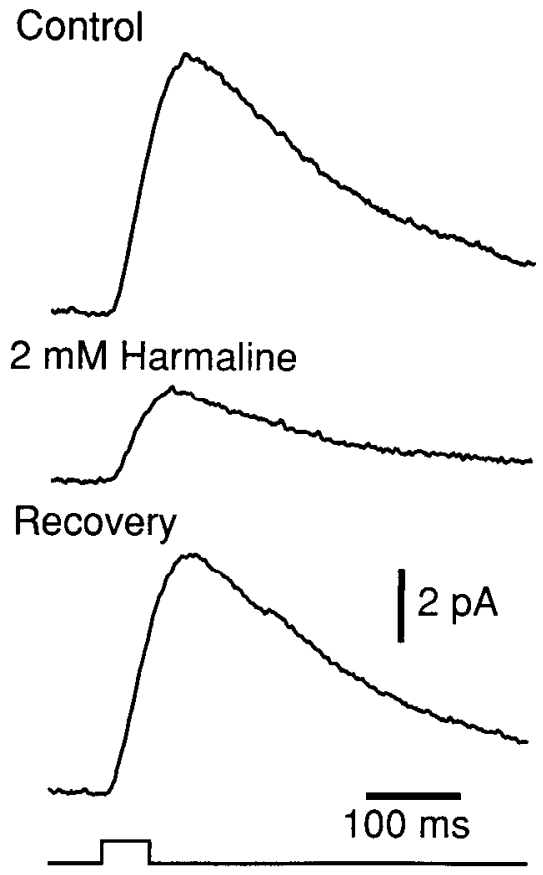

Figure 4. Harmaline block of $\mathrm{HCO}_{3}^{-}$response. Harmaline (2 mM) partially blocked the $\mathrm{HCO}_{3}^{-}$-evoked current. Recovery following washout was rapid and complete. Holding potential, $-6 \mathrm{mV}$.

(Table 2). DIDS binds covalently to an anion site on the $\mathrm{Na}^{+} /$ $\mathrm{HCO}_{3}^{-}$cotransporter (Grassl and Aronson, 1986; Boron and Boulpaep, 1989), but in the dissociated Müller cell preparation, it proved to be partially reversible. Following DIDS washout, the $\mathrm{HCO}_{3}^{-}$response recovered partially over a 5-10 min period, regaining $57 \%$ of its control magnitudc.

DNDS also binds to an anion site on the cotransporter, but in a noncovalent fashion. (This noncovalent interaction has been demonstrated for the $\mathrm{Na}^{+}$-dependent $\mathrm{Cl}^{-} / \mathrm{HCO}_{3}^{-}$exchanger in the squid axon; Boron and Knakal, 1989.) DNDS also blocked the $\mathrm{HCO}_{3}^{-}$-evoked outward current in Müller cells, but only partially. DNDS at $2.0 \mathrm{~mm}$ reduced the $\mathrm{HCO}_{3}^{-}$response to $29 \%$ of control (Fig. 3, Table 2). In contrast to DIDS, the DNDS effect was rapidly (within $2 \mathrm{~min}$ ) and completely reversed.

Harmaline in millimolar concentrations also blocks $\mathrm{Na}^{+} /$ $\mathrm{HCO}_{3}^{-}$cotransport (Grassl et al., 1987; Soleimani and Aronson, 1989) but does so by binding to a cation site (Aronson and Bounds, 1980). Harmaline reduced the $\mathrm{HCO}_{3}^{-}$-evoked outward current to $28 \%$ of control and was rapidly and completely reversible (Fig. 4, Table 2).

The $\mathrm{Na}^{+} / \mathrm{HCO}_{3}^{-}$cotransporter is not blocked by several other transport inhibitors, including amiloride, which blocks $\mathrm{Na}^{+} / \mathrm{H}^{+}$ exchange (Benos, 1982), and ouabain, which blocks the $\mathrm{Na}^{+} / \mathrm{K}^{+}$ ATPase (Skou, 1990). In salamander Müller cells, amiloride and ouabain, in concentrations effective in blocking these other transport systems, had little effect on the $\mathrm{HCO}_{3}^{-}$-evoked response (Table 2). Bicarbonate responses in $1 \mathrm{~mm}$ amiloride were $94 \%$ of control responses. Bicarbonate responses in $10^{-5} \mathrm{M}$ ouabain were $91 \%$ of control.

\section{Ion dependence of $\mathrm{HCO}_{3}^{-}$response}

A fundamental property of the $\mathrm{Na}^{+} / \mathrm{HCO}_{3}^{-}$cotransporter is its dependence on $\mathrm{Na}^{+}$and its independence of $\mathrm{Cl}^{-}$. The ion de-
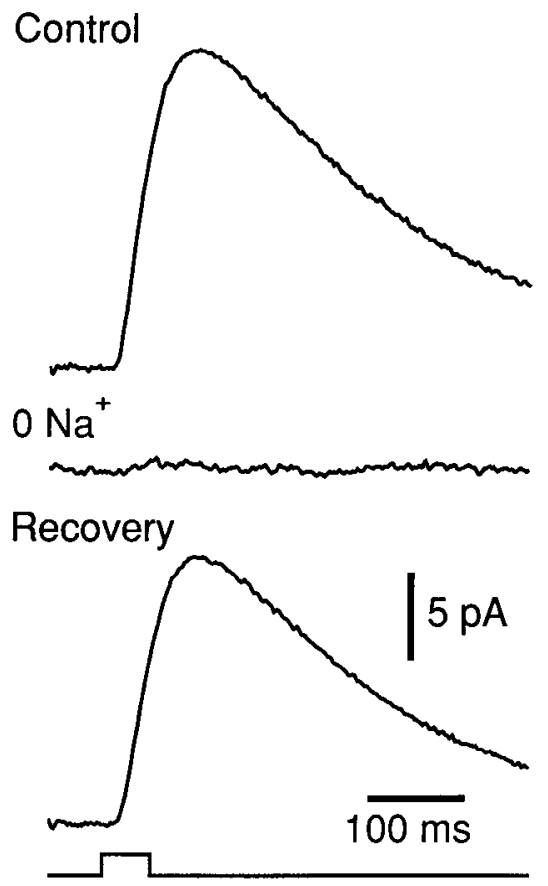

Figure 5. $\mathrm{HCO}_{3}^{-}$response in $\mathrm{Na}^{+}$-free solutions. The outward current evoked by $\mathrm{HCO}_{3}^{-}$ejection was completely inhibited when choline was substituted for $\mathrm{Na}^{+}$in the bath and ejection solutions. This effect was completely and rapidly reversible. Holding potential, $0 \mathrm{mV}$.

pendence of the $\mathrm{HCO}_{3}^{-}$-evoked response in Müller cells was tested in a series of ion substitution experiments.

When choline was substituted for $\mathrm{Na}^{+}$in bath and ejection solutions (Table 1 , nos. 3 and 4), the $\mathrm{HCO}_{3}^{-}$-evoked outward current was almost completely abolished; the magnitude of the response was reduced to just $1.3 \%$ of control (Fig. 5, Table 2). The response recovered completely when $\mathrm{Na}^{+}$was returned to the two solutions. (In this series of experiments, the intracellular solution, no. 8 , was completely $\mathrm{Na}^{+}$free.)

If the cotransporter is dependent on $\mathrm{Na}^{+}$, then raising extracellular $\mathrm{Na}^{+}$in the presence of $\mathrm{HCO}_{3}^{-}$(instead of raising $\mathrm{HCO}_{3}^{-}$in the presence of $\mathrm{Na}^{\prime}$ ) should also evoke an outward current. This prediction was tested in additional ion substitution experiments. Cells were initially bathed in a solution containing $\mathrm{HCO}_{3}^{-}$but lacking $\mathrm{Na}^{+}$(no. 4). A solution containing both $\mathrm{HCO}_{3}^{-}$and $\mathrm{Na}^{+}$(no. 2) was then pressure ejected onto the cell surface. The intracellular solution (no. 10) was $\mathrm{HEPES} / \mathrm{HCO}_{3}^{-}$ buffered.

Raising $\left[\mathrm{Na}^{+}\right]_{0}$ evoked an outward current (Figs. 6, 7). This current was stilbene sensitive, as expected if generated by stimulation of the $\mathrm{Na}^{+} / \mathrm{HCO}_{3}^{-}$cotransportcr. The $\mathrm{Na}^{+}$-cvoked current was reduced to $16.2 \%$ of control by addition of $2 \mathrm{~mm}$ DNDS to bath and ejection solutions (Fig. 6, Table 2). The $\mathrm{Na}^{+}$-evoked response was also $\mathrm{HCO}_{3}^{-}$dependent. Removal of $\mathrm{HCO}_{3}^{-}$from both bath and ejection solutions completely abolished the $\mathrm{Na}^{+}$ response (Fig. 7, Table 2).

The outward current evoked by $\mathrm{Na}^{+}$ejection is the expected response if added $\mathrm{Na}^{+}$is stimulating the $\mathrm{Na}^{+} / \mathrm{HCO}_{3}^{-}$cotransporter. Note that an inward current would be evoked if the ejected $\mathrm{Na}^{+}$were simply entering the cell through a cation channel. Indeed, $\mathrm{Na}^{+}$ejection in the absence of $\mathrm{HCO}_{3}^{-}$evoked a small inward current (Fig. 7, middle trace; Table 2). This current was generated, most likely, by the influx of $\mathrm{Na}^{+}$through an $\mathrm{Na}^{+}$- 


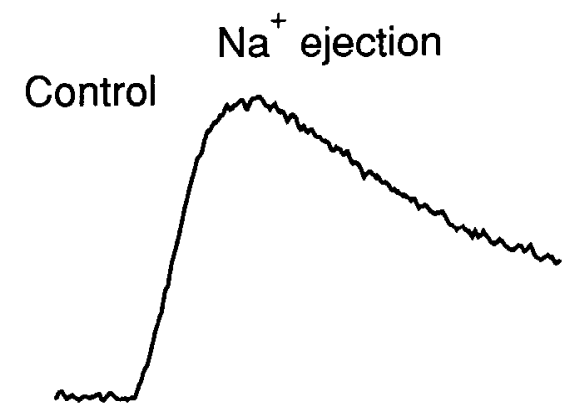

\section{$2 \mathrm{mM}$ DNDS}
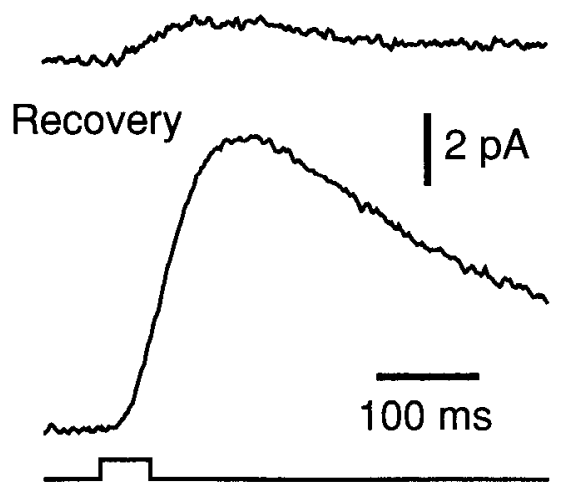

Figure 6. Response to increased $\left[\mathrm{Na}^{+}\right]_{0}$ in presence of $\mathrm{HCO}_{3}^{-}$. The cell was bathed in a $\mathrm{Na}^{+}$-free, $\mathrm{HCO}_{3}^{-}$-buffered solution (Table 1 , no. 4). An outward current was evoked when $\left[\mathrm{Na}^{+}\right]_{\circ}$ was increased by ejection of a $\mathrm{HCO}_{3}^{-}$-buffered solution containing $\mathrm{Na}^{+}$(no. 2). DNDS at $2 \mathrm{~mm}$ substantially reduced the $\mathrm{Na}^{+}$response. The response recovered completely following DNDS washout. Holding potential, $-15 \mathrm{mV}$.

permeable channel. In the presence of $\mathrm{HCO}_{3}^{-}$, this $\mathrm{Na}^{+}$-evoked inward current was masked by the much larger outward current generated by the $\mathrm{Na}^{+} / \mathrm{HCO}_{3}^{-}$cotransporter.

The outward current generated by Müller cells in response to $\mathrm{HCO}_{3}^{-}$ejections was independent of $\mathrm{Cl}^{-} . \mathrm{HCO}_{3}^{-}$responses of normal magnitude were recorded when methane sulfonate was substituted for $\mathrm{Cl}^{-}$in intracellular, bath, and ejection solutions (nos. 16, 11, and 12, respectively; Fig. 8). The effect of $\mathrm{Cl}$ removal was evaluated in a population of cells by comparing the magnitude of $\mathrm{HCO}_{3}$-evoked responses in the presence and absence of the anion. When methane sulfonate was substituted for $\mathrm{Cl}^{-}$, the magnitude of the $\mathrm{HCO}_{3}^{-}$-evoked outward current averaged $1.27 \pm 0.13 \mathrm{pC}$ (picocoulombs; $n=11$; during a 450 msec period following $\mathrm{HCO}_{3}^{-}$ejection; Table 2). This is almost identical to the value of $1.30 \pm 0.09 \mathrm{pC}(n=25)$ obtained for responses recorded in $\mathrm{Cl}^{-}$-containing solutions. These results demonstrate that $\mathrm{Cl}^{-}$is not needed to generate the $\mathrm{HCO}_{3}^{-}$response.

\section{pH and $\mathrm{CO}_{2}$ controls}

In the $\mathrm{HCO}_{3}^{-}$ejection experiments illustrated in Figures 1-5, the $\mathrm{pH}$ values of the bath solution (nominally $\mathrm{HCO}_{3}^{-}$free) and ejection solution $\left(26 \mathrm{mM} \mathrm{HCO}_{3}^{-}\right.$) were made equal by bubbling the bath with $100 \% \mathrm{O}_{2}$ and the ejection solution with $5 \% \mathrm{CO}_{2}$ in $\mathrm{O}_{2}$. Thus, besides raising $\left[\mathrm{HCO}_{3}^{-}\right]_{0}$, ejections also raised external $\mathrm{pCO}_{2}$, which, in turn, could lead to an increase in internal $\mathrm{pCO}_{2}$ and a decrease in $\mathrm{pH}_{\mathrm{i}}$. In addition, it is likely that the $\mathrm{pCO}_{2}$ of the solution within the ejection pipette declined some-

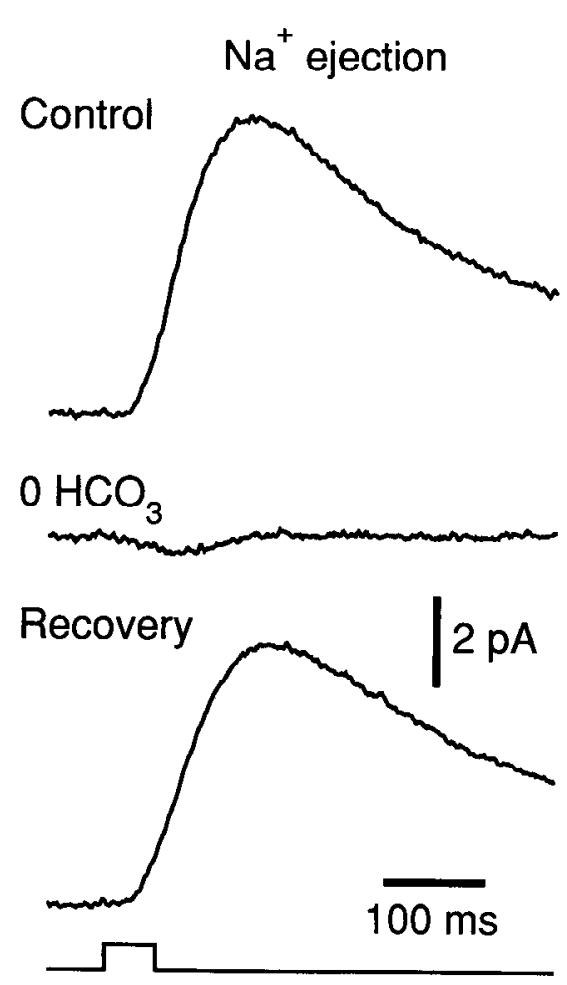

Figure 7. $\mathrm{Na}^{+}$response in $\mathrm{HCO}_{3}^{-}$-free solutions. The outward current evoked by $\mathrm{Na}^{+}$ejection was completely abolished when $\mathrm{HCO}_{3}^{-}$was removed from bath and ejection solutions (Table 1 , nos. 3 and 1 , respectively). $\mathrm{Na}^{+}$ejection in the absence of $\mathrm{HCO}_{3}^{-}$evoked a small inward current, which may reflect the influx of $\mathrm{Na}^{+}$through an $\mathrm{Na}^{+}$-permeable channel. Holding potential, $-10 \mathrm{mV}$.

what during an experiment, thus raising the pII of the ejection solution. Thus, it is possible that the $\mathrm{HCO}_{3}^{-}$responses illustrated in Figures $1-5$ reflect a change in $\mathrm{pH}$ or $\mathrm{pCO}_{2}$ rather than a change in $\left[\mathrm{HCO}_{3}^{-}\right]_{0}$. The following two experiments were conducted to test this possibility.

In the first experiment, $\left[\mathrm{HCO}_{3}^{-}\right]_{0}$ was varied while keeping $\mathrm{pCO}_{2}$ constant. The bath solution (Table 1 , no. 5) contained 2

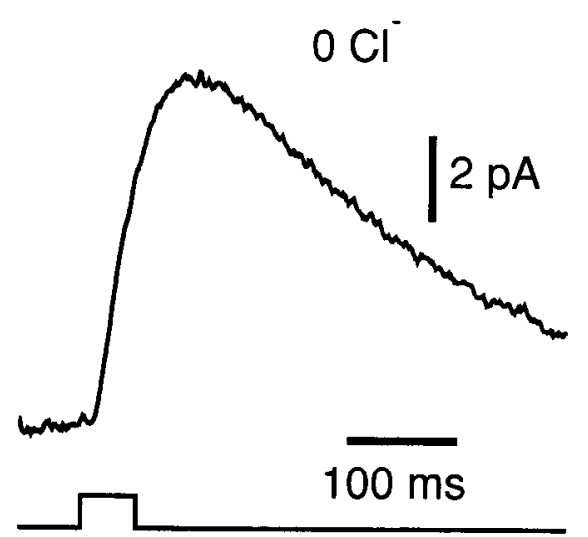

Figure 8. $\quad \mathrm{HCO}_{3}^{-}$response in $\mathrm{Cl}^{-}$-free solutions. Methane sulfonate was substituted for $\mathrm{Cl}^{-}$in bath, ejection, and intracellular solutions (Table 1 , nos. 11,12 , and 16 , respectively). $\mathrm{HCO}_{3}^{-}$ejection evoked an outward current whose magnitude and time course were similar to those seen in solutions containing $\mathrm{Cl}^{-}$. At the time this record was made, the cell had been bathed in $\mathrm{Cl}^{-}$-free solution for $29 \mathrm{~min}$ and had been internally perfused with $\mathrm{Cl}^{-}$-free solution for $8 \mathrm{~min}$. Holding potential, $-15 \mathrm{mV}$. 


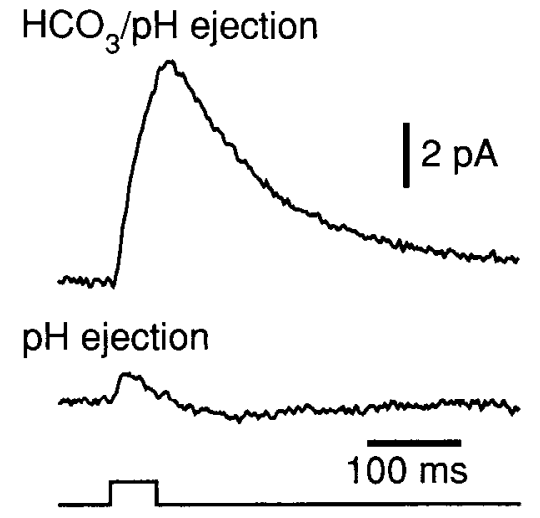

Figure 9. Responses to increased $\mathrm{HCO}_{3}^{-}$and $\mathrm{pH}$. Top, Cell bathed in a low $\left[\mathrm{HCO}_{3}^{-}\right] / \mathrm{CO}_{2}$ solution (Table 1 , no. 5). A high $\left[\mathrm{HCO}_{3}^{-}\right] / \mathrm{CO}_{2}$ solution (no. 6) was ejected onto the endfoot. Ejection raised $\left[\mathrm{HCO}_{3}^{-}\right]_{\mathrm{o}}$ and $\mathrm{pH}_{\circ}$ but did not alter $\mathrm{pCO}_{2}$. The ejection evoked an outward current similar to those seen in the "standard" $\mathrm{HCO}_{3}^{-}$-ejection experiments. (The intracellular solution, no. 7, was HEPES buffered. Following equilibration with $\mathrm{CO}_{2}$ in the bath, intracellular $\mathrm{pH}$ dropped to $\sim 6.4$ and $\left[\mathrm{HCO}_{3}^{-}\right]_{\mathrm{i}}$ rose to $\sim 2.2 \mathrm{~mm}$.) Bottom, A different cell bathed in a $\mathrm{pH}$ 6.4, HEPES-buffered solution (no. 1). A pH 7.5, HEPES-buffered solution (no. 1) was ejected onto the endfoot. Ejection, which raised $\mathrm{pH}_{\mathrm{o}}$ but did not alter $\left[\mathrm{HCO}_{3}^{-}\right]_{\mathrm{o}}$ or $\mathrm{pCO}_{2}$, resulted in a more transient and much diminished outward current response. Holding potential for both cells, $-20 \mathrm{mV}$.

$\mathrm{mM} \mathrm{HCO}_{3}^{-}$and had a $\mathrm{pH}$ of $6.4\left(5 \% \mathrm{CO}_{2}\right)$. The ejection solution (no. 6) contained $26 \mathrm{mM} \mathrm{HCO}_{3}^{-}$and had a pH of $7.5\left(5 \% \mathrm{CO}_{2}\right)$. Ejection of this solution, which raised $\left[\mathrm{HCO}_{3}^{-}\right]_{0}$ and $\mathrm{pH}_{\mathrm{o}}$ but did not change $\mathrm{pCO}_{2}$, evoked an outward current that was similar in magnitude and time course (Fig. 9, top) to those seen in standard $\mathrm{HCO}_{3}^{-}$ejection experiments.

The second experiment served as a $\mathrm{pH}$ control for the first. The bath and ejection solutions (both no. 1) were HEPES buffered and were nominally $\mathrm{HCO}_{3}^{-}$free. The bath solution was titrated to $\mathrm{pH} 6.4$ and the ejection solution to $\mathrm{pH} 7.5$ (matching the $\mathrm{pH}$ values of the preceding experiment). Raising $\mathrm{pH}_{\mathrm{o}}$ generated an outward current (Fig. 9, bottom) that was far smaller in magnitude and shorter in time course than was the current generated by the $\left[\mathrm{HCO}_{3}^{-}\right]_{0}$ increase. The magnitude of the response to the $\mathrm{HCO}_{3}^{-}$increase (Fig. 9, top) was 19.3 times larger $(n=10)$ than was the magnitude of the response to the $\mathrm{pH}$ change (Fig. 9, bottom). It can be safely concluded from these two experiments that the $\mathrm{HCO}_{3}^{-}$response is not generated by a change in $\mathrm{pH}_{\mathrm{o}}$ and that a $\mathrm{HCO}_{3}^{-}$response can be evoked in the absence of a change in $\mathrm{pCO}_{2}$.

(The $\mathrm{Na}^{+}$ejection experiments illustrated in Figures 6 and 7 serve as additional $\mathrm{CO}_{2}$ and $\mathrm{pH}$ controls. Bath and ejection solutions had equal $\left[\mathrm{HCO}_{3}^{-}\right], \mathrm{pH}$, and $\mathrm{pCO}_{2}$. The outward current seen in the $\mathrm{Na}^{+}$ejection experiments was evoked solely by an increase in $\left[\mathrm{Na}^{+}\right]_{0}$ )

\section{Summary of $\mathrm{HCO}_{3}^{-}$ejection experiments}

The outward current generated by dissociated salamander Müller cells in response to an increase in $\left[\mathrm{HCO}_{3}^{-}\right]_{0}$ has the following properties: (1) it is blocked by the stilbenes DIDS and DNDS and by harmaline, (2) it is not blocked by the transport inhibitors amiloride and ouabain, (3) it is $\mathrm{Na}^{+}$dependent but $\mathrm{Cl}^{-}$independent, and (4) it is generated by the $\left[\mathrm{HCO}_{3}^{-}\right]_{0}$ increase rather than by changes in $\mathrm{pH}$ or $\mathrm{pCO}_{2}$. These properties strongly indicate that the $\mathrm{HCO}_{3}^{-}$-evoked outward current is generated by

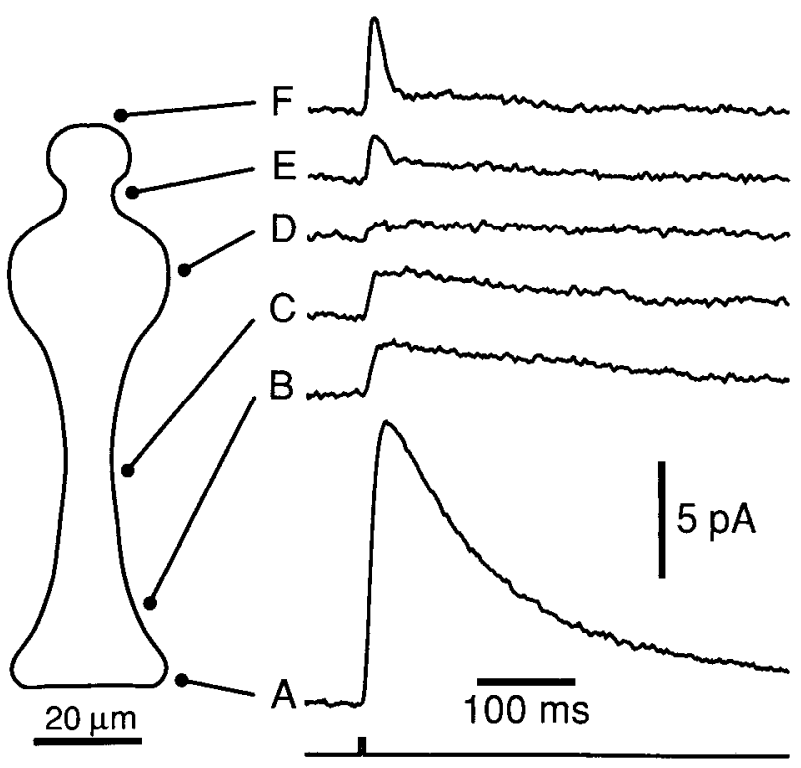

Figure 10. Localization of $\mathrm{HCO}_{3}^{-}$response. Cell bathed in HEPESbuffered solution (Table 1, no. 1). $\mathrm{A} \mathrm{HCO}_{3}^{-}$-buffered solution (no. 2) was ejected onto different regions of the Müller cell surface. Drawing to the left shows ejection locations for a typical cell: $A$, endfoot; $B$, proximal end of proximal process; $C$, middle of proximal process; $D$, soma; $E$, distal process; $F$, distal end of cell. The $\mathrm{HCO}_{3}^{-}$response was largest at the endfoot (site $A$ ). A second, more transient response was evoked at the distal end of the cell (sites $E$ and $F$ ). Holding potential, $-10 \mathrm{mV}$.

an electrogenic $\mathrm{Na}^{+} / \mathrm{HCO}_{3}^{-}$cotransporter having properties similar to those seen in other systems.

\section{Spatial distribution of $\mathrm{Na}^{+} / \mathrm{HCO}_{3}^{-}$cotransporter}

The spatial distribution of the $\mathrm{Na}^{+} / \mathrm{HCO}_{3}^{-}$cotransporter was determined by ejecting $\mathrm{HCO}_{3}^{-}$onto different regions of the Müller cell surface. A large response was evoked when $\mathrm{HCO}_{3}^{-}$was ejected onto the endfoot of the cell (Fig. 10, site A), while smaller responses were recorded for ejections onto other cell regions (Fig. 10, sites B-F). The magnitude of the response decreased monotonically as the ejection site was moved distally (away from the endfoot). $\mathrm{HCO}_{3}^{-}$ejection response magnitudes, normalized to the endfoot response, were as follows: site $\mathrm{A}$, endfoot, $100 \%$; B, proximal end of proximal process, $54.3 \pm 20.7 \%$; $\mathrm{C}$, midproximal process, $44.4 \pm 4.5 \%$; $D$, soma, $15.3 \pm 1.8 \%$; $\mathrm{E}$, distal process, $14.1 \pm 1.5 \%$; F distal end of cell, $10.0 \pm 1.8 \%$ ( $n=18 ; n=2$ for site B).

A rapid outward current, superimposed on the slower cotransport current, was evoked when $\mathrm{HCO}_{3}^{-}$was ejected onto the distal end of Müller cells (Fig. 10, sites E and F). Additional experiments demonstrated that this transient current was $\mathrm{Na}^{+}$ independent. When $\mathrm{Na}^{+}$was removed from the bath and ejection solutions, the slower $\mathrm{HCO}_{3}^{-}$-evoked response was abolished while the faster transient remained.

In contrast to the cotransport response, the rapid, $\mathrm{Na}^{+}$-independent component of the $\mathrm{HCO}_{3}^{-}$response was localized preferentially to the distal end of Müller cells. In the absence of $\mathrm{Na}^{+}$ in both bath (Table 1, no. 3) and ejection (no. 4) solutions, ejection of $\mathrm{HCO}_{3}^{-}$evoked an outward current that was largest at the distal end of the cell. Response magnitudes, normalized to the response at the distal end, were as follows: site A, endfoot, $24.0 \pm 7.0 \%$; $\mathrm{C}$, midproximal process, $21.8 \pm 8.3 \%$; D, soma, 


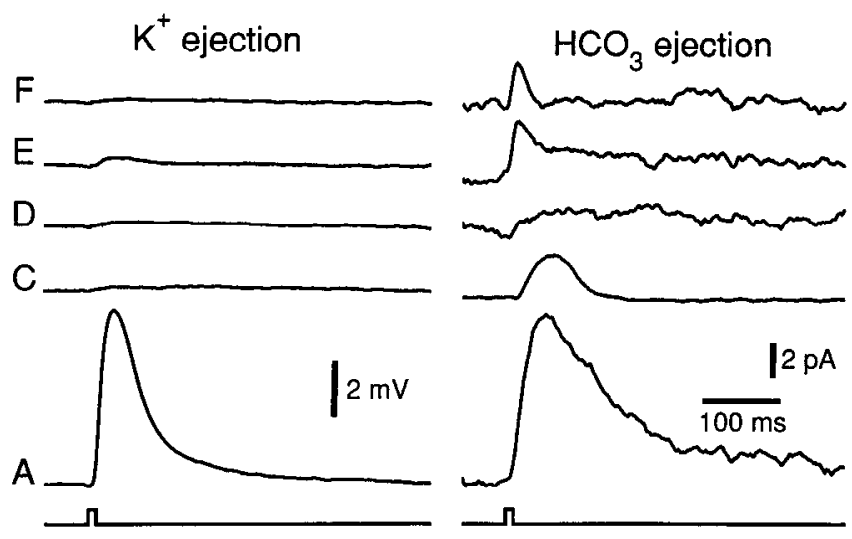

Figure 11. Localization of $\mathrm{K}^{+}$and $\mathrm{HCO}_{3}^{-}$rcsponses in a single cell. $\mathrm{K}^{+}$ejection, Cell bathed in HEPES-buffered solution with $2.5 \mathrm{mM}\left[\mathrm{K}^{+}\right]$ (Table 1 , no. $1, \mathrm{Ba}^{2+}$ omitted). An ejection solution containing $7.5 \mathrm{~mm}$ $\left[\mathrm{K}^{+}\right]$(no. 1, $\mathrm{Ba}^{2+}$ omitted, $5 \mathrm{mM} \mathrm{KCl}$ added) was ejected onto different cell sites from one barrel of a double-barreled pipette. Intracellular solution (no. 9) contained $\mathrm{KCl}$ instead of $\mathrm{CsCl}$. Cell current-clamped (cell potential, $-84 \mathrm{mV}$ ). $\mathrm{K}^{+}$ejection evoked a far larger depolarization at the cell endfoot (site $\mathrm{A}$ ) than at all other ejection sites. $\mathrm{HCO}_{3}^{-}$ejection, The same cell bathed in HEPES-buffered solution with $\mathrm{Ba}^{2+}$ added (no. 1). $\mathrm{A} \mathrm{HCO}_{3}^{-}$-buffered solution (no. 2) was ejected onto the same sites from the second barrel of the ejection pipette. Cell voltage-clamped (holding potential, $-18 \mathrm{mV}$ ). $\mathrm{HCO}_{3}^{-}$ejection evoked a larger response at the endfoot (site $A$ ) than at other cell regions. Ejection sites are the same as in Figure 10 . Note that the $\mathrm{HCO}_{3}^{-}$ejection records are noisy due to the omission of $\mathrm{Cs}^{+}$from the recording pipette solution.

$33.3 \pm 7.5 \%$; E, distal process, $86.1 \pm 8.2 \%$; , distal end of cell, $100 \%(n=9)$. It is possible that this $\mathrm{HCO}_{3}^{-}$-evoked, $\mathrm{Na}^{+}-$ independent current is generated by the influx of $\mathrm{HCO}_{3}^{-}$through an anion channel.

We have previously demonstrated that $\mathrm{K}^{+}$channels, as well as cotransporter sites, are localized to the endfeet of amphibian Müller cells (Newman, 1984, 1985a). In the present study, the distributions of both $\mathrm{Na}^{+} / \mathrm{HCO}_{3}^{-}$cotransporter sites and $\mathrm{K}^{+}$ channels were determined in single cells in order to compare the degree of localization of these two systems. $\mathrm{K}^{+}$channel distribution was first measured by ejecting a solution containing $7.5 \mathrm{mM} \mathrm{K}^{+}$sequentially onto cell sites A-F from one barrel of a double-barreled ejection pipette. For technical reasons, the voltage response, rather than the current response, was recorded. The distribution of cotransporter sites was then measured by ejecting a $\mathrm{HCO}_{3}^{-}$-buffered solution onto the same sites $\mathrm{A}-\mathrm{F}$ from the second barrel of the pipette.

Results contirm that both $\mathrm{K}^{+}$channels and $\mathrm{Na}^{+} / \mathrm{HCO}_{3}^{-}$cotransporter sites are localized preferentially to the Müller cell endfoot (Fig. 11). It is clear, howcver, that $\mathrm{K}^{+}$channel localization to the endfoot is far more extreme than is localization of the cotransporter.

\section{Reversal potential of $\mathrm{HCO}_{3}^{-}$response}

The reversal potential of the $\mathrm{Na}^{+} / \mathrm{HCO}_{3}^{-}$cotransport system was determined in order to calculate cotransporter stoichiometry (the ratio of $\mathrm{HCO}_{3}^{-}$to $\mathrm{Na}^{+}$transported). The reversal potential varies as a function of the transmembrane $\mathrm{HCO}_{3}^{-}$and $\mathrm{Na}^{+}$gradients. In the present study, the reversal potential was measured using four different combinations of external and internal $\left[\mathrm{Na}^{+}\right]$, yielding $\mathrm{Na}^{+}$gradients of $1,1.8,3.7$, and 7.4 to 1 (external to internal). In these experiments, $\left[\mathrm{HCO}_{3}^{-}\right]_{\mathrm{o}}$ equaled $\left[\mathrm{HCO}_{3}^{-}\right]_{\mathrm{i}}$. In-

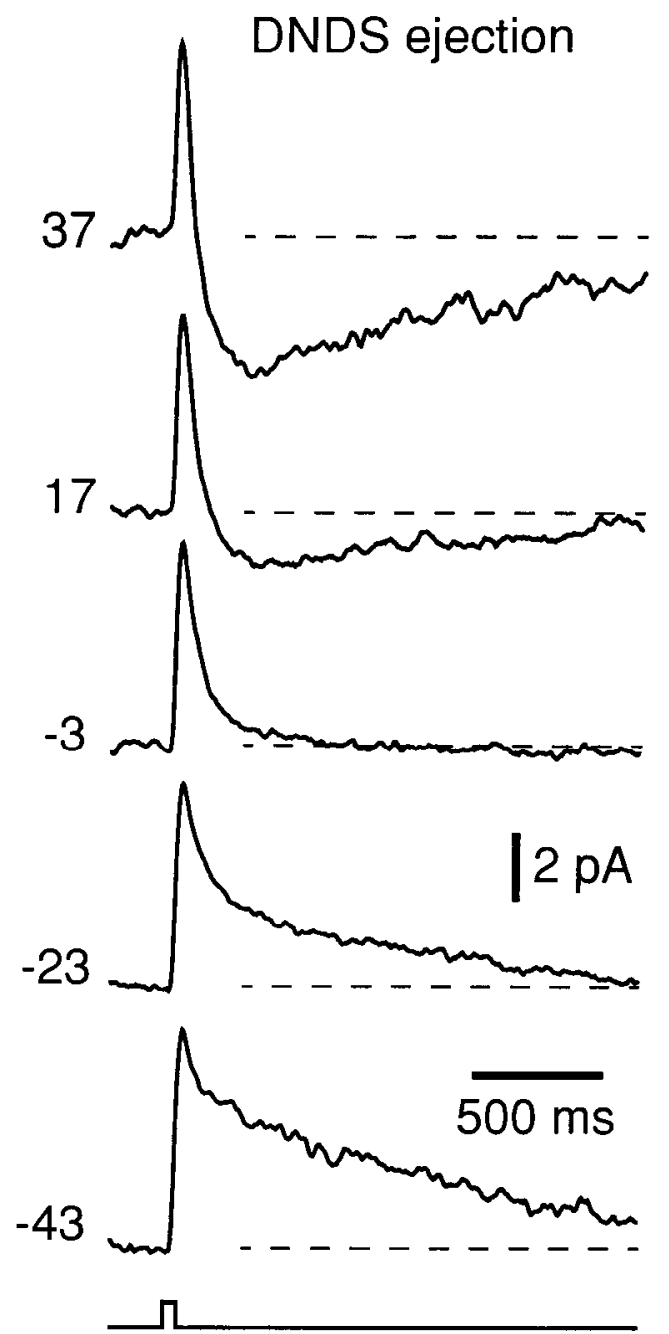

Figure 12. Reversal potential of $\mathrm{HCO}_{3}^{-}$response. The cell was bathed in $\mathrm{HCO}_{3}^{-}$-buffered solution (Table 1, no. 13) and internally perfused with $\mathrm{HCO}_{3}^{-}$-buffered intracellular solution (no. 17). The ejection solution (no. 13 with $2 \mathrm{~mm}$ DNDS added) was ejected onto the endfoot as the cell was voltage clamped (holding potentials, in millivolts, indicated to the $l c f t$. DNDS ejection produced a transient, voltage-independent outward current followed by a more sustained current whose polarity and magnitude varied as a function of the holding potential. This slower component, generated by DNDS block of the $\mathrm{Na}^{1} / \mathrm{HCO}_{3}^{-}$cotransport current, reversed polarity near $-3 \mathrm{mV}$.

tracellular solutions (contained in the recording pipette) were buffered with 106 mM HEPES. This high buffer concentration helped to hold $\mathrm{pH}_{\mathrm{i}}$ constant. Bccausc $\mathrm{CO}_{2}$ was held constant at $5 \%$, clamping $\mathrm{pH}_{\mathrm{i}}$ also served to hold $\left[\mathrm{HCO}_{3}^{-}\right]_{\mathrm{i}}$ constant. In order to maintain a constant $\left[\mathrm{Na}^{+}\right]_{\text {, }}$, the cell $\mathrm{Na}^{+} / \mathrm{K}^{+}$-ATPase was inhibited by addition of ouabain to the bath at $2 \cdot 10^{-5} \mathrm{M}$, a concentration effective in blocking the ATPase in Müller cells (Newman, 1985a). All solutions were nominally $\mathrm{Cl}^{-}$free.

The reversal potential of the cotransporter was determined by monitoring cell responses to the ejection of DNDS as cells were clamped at different holding potentials. DNDS blocked the cotransporter in a reversible manner and led to a reduction in cotransporter current. The use of $\mathrm{Cl}^{-}$-free solutions minimized currents evoked by DNDS block of anion channels.

DNDS ejections evoked a two-component response, a tran- 


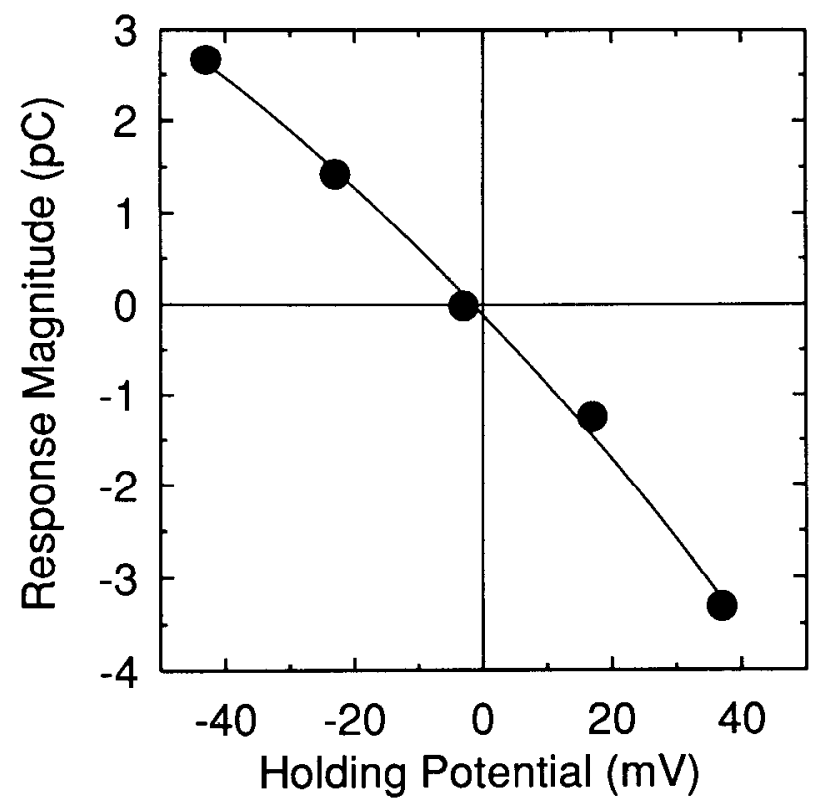

Figure 13. Magnitude of the voltage-dependent, DNDS-evoked current as a function of the cell holding potential. Data are from experiment illustrated in Figure 12. The DNDS response reversed polarity at -2.5 $\mathrm{mV}$, near the predicted cotransporter reversal potential of $0 \mathrm{mV}$. Response magnitude was measured as the area of the responses from 500 to $2000 \mathrm{msec}$ following ejection onset. (This period is indicated by the broken lines in Fig. 12.) Data were fit by a second-order polynomial.

sient outward current followed by a slower current whose magnitude and polarity varied as a function of the holding potential (Fig. 12). The magnitude of the transient outward current was essentially voltage independent, varying only $6 \%$ for holding potentials ranging from -40 to $+20 \mathrm{mV}$. The origin of this outward current is not known. It could possibly represent a stilbene flux through an anion channel, although this seems unlikely since stilbenes are known to bind to but not to permeate through anion channels.

In contrast to the transient outward current, the slower current was voltage dependent. It reflects a DNDS block of the $\mathrm{Na}^{+}$/ $\mathrm{HCO}_{3}^{-}$cotransporter. In the experiment illustrated in Figure 12, the voltage-dependent component of the current reversed polarity near $-3 \mathrm{mV}$.

The precise value of the reversal potential was calculated by plotting the magnitude of the DNDS-induced current as a function of holding potential (Fig. 13). In the example illustrated, the reversal potential was $-2.5 \mathrm{mV}$.

The reversal potential was determined in this manner for a total of 57 cells and four different transmembrane $\mathrm{Na}^{+}$gradients. The measured reversal potentials for each of the $\mathrm{Na}^{+}$gradients, along with the predicted reversal potentials for stoichiometries of 2,3 , and 4 , are given in Table 3 .

\section{Discussion}

\section{Electrogenic $\mathrm{Na}^{+} / \mathrm{HCO}_{3}^{-}$cotransport}

The experiments reported here demonstrate that salamander Müller cells possess an electrogenic $\mathrm{Na}^{+} / \mathrm{HCO}_{3}^{-}$cotransport system. Raising either $\left[\mathrm{HCO}_{3}^{-}\right]_{\mathrm{o}}$ in the presence of $\mathrm{Na}^{+}$or $\left[\mathrm{Na}^{+}\right]_{\circ}$ in the presence of $\mathrm{HCO}_{3}^{-}$leads to the generation of an outward current, consistent with the influx of $\mathrm{HCO}_{3}^{-}$and $\mathrm{Na}^{+}$into the cell (with a $\mathrm{HCO}_{3}^{-}: \mathrm{Na}^{+}$stoichiometry greater than 1). Control
Table 3. Reversal potential of $\mathrm{Na}^{+} / \mathrm{HCO}_{3}^{-}$cotransport current

\begin{tabular}{|c|c|c|c|c|c|c|c|}
\hline \multirow[b]{2}{*}{ Case } & \multicolumn{2}{|c|}{$\begin{array}{l}\text { Ion con- } \\
\text { centration } \\
\text { (mM) }\end{array}$} & \multicolumn{3}{|c|}{ Predicted $E_{\text {reversal }}(\mathrm{mV})$} & \multirow{2}{*}{$\begin{array}{l}\text { Measured } \\
E_{\text {reversal }}(\mathrm{mV}) \\
\end{array}$} & \multirow[b]{2}{*}{$n$} \\
\hline & {$\left[\mathrm{Na}^{+}\right]_{0}$} &.$\left[\mathrm{Na}^{+}\right]_{\mathrm{i}}$ & $2: 1$ & $3: 1$ & $4: 1$ & & \\
\hline 1 & 26 & 26 & 0 & 0 & 0 & $-0.1 \pm 1.3$ & 15 \\
\hline 2 & 48 & 26 & -15.4 & -7.7 & -5.1 & $-9.9 \pm 1.2$ & 11 \\
\hline 3 & 96 & 26 & -32.9 & -16.5 & -11.0 & $-21.4 \pm 1.5$ & 17 \\
\hline 4 & 96 & 13 & -50.4 & -25.2 & -16.8 & $-25.5 \pm 2.0$ & 14 \\
\hline
\end{tabular}

Measured reversal potential values given as mean \pm SEM. In all cases, $\left[\mathrm{HCO}_{3}^{-}\right]$ and $\left[\mathrm{HCO}_{3}^{-}\right]_{\mathrm{i}}$ equaled $26 \mathrm{~mm}$. Bath solution nos. 13, 14, 15, and 15 (Table 1 ) were used in cases 1-4, respectively. Intracellular solution no. 17 was used in cases 13 and solution no. 18 in case 4 . Predicted reversal potentials for stoichiometries of 2, 3, and 4 to 1 were calculated from Equation 1 .

experiments demonstrate that this current is not generated by variations in external $\mathrm{pH}$ or $\mathrm{CO}_{2}$.

The properties of the Müller cell $\mathrm{Na}^{+} / \mathrm{HCO}_{3}^{-}$cotransporter are similar to those observed in other systems. The Müller cell cotransporter is inhibited by millimolar concentrations of the stilbenes DIDS and DNDS, which block cotransport in the proximal tubule (Grassl and Aronson, 1986; Soleimani and Aronson, 1989), the ciliary epithelium (Helbig et al., 1989), the retinal pigment epithelium (Hughes et al., 1989), and leech glial cells (Deitmer and Schlue, 1989). As in the proximal tubule, the cotransporter is inhibited by millimolar concentrations of harmaline (Grassl et al., 1987; Soleimani and Aronson, 1989). The Müller cell cotransporter is dependent on $\mathrm{Na}^{+}$but is independent of $\mathrm{Cl}^{-}$, as it is in other systems (Boron and Boulpaep, 1989).

\section{Localization of the cotransporter}

The focal $\mathrm{HCO}_{3}^{-}$-ejection experiments reported here have permitted, for the first time in any system, the localization of cotransporter sites on the surface of single cells. The results indicate that the $\mathrm{Na}^{+} / \mathrm{HCO}_{3}^{-}$cotransporter is localized primarily at the endfoot of salamander Müller cells; the largest $\mathrm{HCO}_{3}^{-}$ currents were evoked when ejections were directed at this cell region. The Müller cell endfoot is also the site of a high density of $\mathrm{K}^{+}$channels (Newman, 1984, 1987; Brew et al., 1986). In salamander, $90-95 \%$ of all $\mathrm{K}^{+}$channels in the Müller cell are localized to the endfoot (Newman, 1985a). Localization of both cotransporter sites and $\mathrm{K}^{+}$channels to the cell endfoot demonstrates that Müller cells share a property common to epithelial cells: they are functionally polarized. This polarization suggests that Müller cells have physiological functions similar to those of epithelia. Specifically, the asymmetric distribution of cotransporter sites might enable Müller cells to regulate changes in $\mathrm{pH}_{\mathrm{o}}$ by transporting $\mathrm{HCO}_{3}^{-}$across the retina (see below).

Not all membrane channels and transporters are localized to the endfoot in Müller cells. In this study, the $\mathrm{Na}^{+}$-independent $\mathrm{HCO}_{3}^{-}$response was largest at the distal end of the cell (the end opposite the endfoot), suggesting that Müller cells possess an anion channel that is localized to this cell region. The channel underlying this reponse has not been characterized, although anion channels have been identified in other glial cells (Ritchie, 1987).

\section{Stoichiometry of the cotransporter}

The stoichiometry of the $\mathrm{Na}^{+} / \mathrm{HCO}_{3}^{-}$cotransport system can be calculated from a knowledge of the transmembrane $\mathrm{HCO}_{3}^{-}$and $\mathrm{Na}^{+}$gradients and the cotransporter reversal potential. The re- 
lation between stoichiometry and these parameters is given by the equation (Lopes et al., 1987)

$$
E_{\text {reversal }}=\frac{R T}{F(n-1)} \ln \frac{\left[\mathrm{Na}^{+}\right]_{i}\left[\mathrm{HCO}_{3}^{-}\right]_{1}^{n}}{\left[\mathrm{Na}^{+}\right]_{0}\left[\mathrm{HCO}_{3}^{-}\right]_{0}^{n}}
$$

where $n$ is the stoichiometry (the $\mathrm{HCO}_{3}^{-}: \mathrm{Na}^{+}$transport ratio); $R, T$, and $F$ have their usual meanings; and $\left[\mathrm{Na}^{+}\right]_{i}$ and $\left[\mathrm{HCO}_{3}^{-}\right]_{i}$ are the intracellular concentrations of $\mathrm{Na}^{+}$and $\mathrm{HCO}_{3}^{-}$.

As indicated in Table 3, the measured cotransporter reversal potential varied systematically as the transmembrane $\mathrm{Na}^{+}$gradient was changed. In these experiments, cotransporter current was driven solely by the $\mathrm{Na}^{+}$gradient; there was no $\mathrm{HCO}_{3}^{-}$ gradient, as both $\left[\mathrm{HCO}_{3}^{-}\right]_{\mathrm{o}}$ and $\left[\mathrm{HCO}_{3}^{-}\right]_{\mathrm{i}}$ were equal to $26 \mathrm{mM}$. When $\left[\mathrm{Na}^{+}\right]_{0}$ and $\left[\mathrm{Na}^{+}\right]_{i}$ were both $26 \mathrm{~mm}$ (Table 3 , case 1 ), the measured reversal potential was very near the predicted value of $0 \mathrm{mV}$. As the $\mathrm{Na}^{+}$gradient was increased (by raising $\left[\mathrm{Na}^{+}\right]_{\text {。 }}$ and by lowering $\left[\mathrm{Na}^{+}\right]_{\mathrm{i}}$ ), the measured reversal potential grew more negative.

The relation between the $\mathrm{Na}^{+}$gradient and the measured reversal potential is shown graphically in Figure 14, along with the predicted reversal potential relations for cotransporter stoichiometries of 2,3 , and 4 . The measured values for the cotransporter reversal potential lie close to those predicted for a stoichiometry of 3 . A least-squares fit to the data predicts a stoichiometry of $2.80 \pm 0.13$, close to a value of 3 . In a previous, preliminary report (Newman and Astion, 1991), the reversal potential was measured in Müller cells as the transmembrane $\mathrm{HCO}_{3}^{-}$gradient, rather than the $\mathrm{Na}^{+}$gradient, was varied. In this case as well, the measured reversal potential was very close to the value predicted for a 3:1 stoichiometry.

The stoichiometry of the $\mathrm{Na}^{+} / \mathrm{HCO}_{3}^{-}$cotransport system has been determined in several other systems. A stoichiometry of 3:1 has been calculated for mammalian proximal tubule cells using several different techniques, including intracellular measurements of $\left[\mathrm{Na}^{+}\right]$and $\mathrm{pH}$ (Yoshitomi et al., 1985) and $\mathrm{Na}^{+}$ flux measurements in membrane vesicles (Soleimani et al., 1987). In contrast, a cotransporter stoichiometry of $2: 1$ has been estimated for amphibian optic nerve astrocytes (Astion et al., 1989a), leech glial cells (Deitmer and Schlue, 1989), and frog retinal pigment epithelium cells (Hughes et al., 1989).

This variation in stoichiometry may reflect differences in cotransporter function in different systems. When $\mathrm{HCO}_{3}^{-}$is transported out of a cell (e.g., the kidney proximal tubule), a stoichiometry of at least 3:1 is needed to supply sufficient energy to oppose the inwardly directed $\mathrm{Na}^{+}$gradient. When $\mathrm{HCO}_{3}^{-}$is transported into a cell, in contrast (e.g., the retinal pigment epithelium), the $\mathrm{Na}^{+}$gradient aids in $\mathrm{HCO}_{3}^{-}$transport and a stoichiometry of $2: 1$ is sufficient to transport the $\mathrm{HCO}_{3}^{-}$. A cotransporter stoichiometry of 3:1 in retinal Müller cells suggests that $\mathrm{HCO}_{3}^{-}$is normally transported in an outward direction in these cells (see below).

\section{Cotransporter fluxes in vivo}

Direction of cotransporter flux. The direction of $\mathrm{Na}^{+} / \mathrm{HCO}_{3}^{-}$flux in Müller cells in vivo can be determined by estimating the reversal potential of the cotransporter under physiological conditions. If one assumes that in vivo, $\left[\mathrm{HCO}_{3}^{-}\right]_{\circ}=26 \mathrm{~mm}$, $\left[\mathrm{HCO}_{3}^{-}\right]_{\mathrm{i}}=9 \mathrm{~mm},\left[\mathrm{Na}^{+}\right]_{\mathrm{o}}=110 \mathrm{~mm}$, and $\left[\mathrm{Na}^{+}\right]_{\mathrm{i}}=20 \mathrm{~mm}$, a cotransporter reversal potential of $-62 \mathrm{mV}$ is calculated from Equation 1. $\left(\left[\mathrm{HCO}_{3}^{-}\right]_{i}\right.$ is derived assuming $\mathrm{pH}_{1}=7.1$ and $\mathrm{pCO}_{2}$ $=37 \mathrm{~mm} \mathrm{Hg}$.) A reversal potential of $-62 \mathrm{mV}$ is somewhat

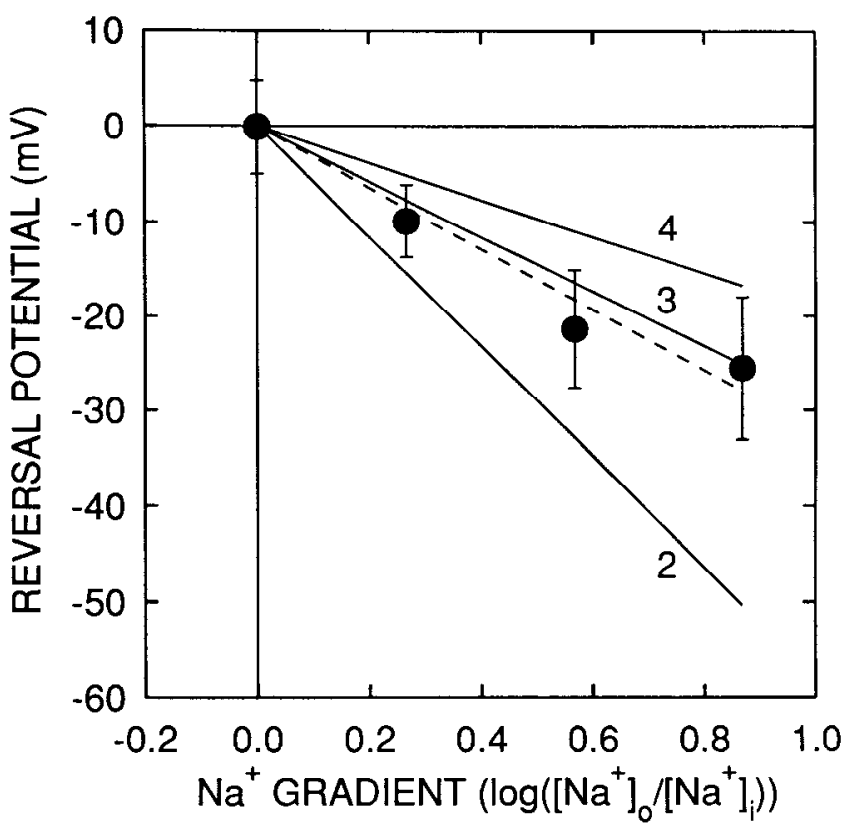

Figure 14. Reversal potential of the $\mathrm{Na}^{+} / \mathrm{HCO}_{3}^{-}$cotransporter as a function of the transmembrane $\mathrm{Na}^{+}$gradient. Data $\pm \mathrm{SD}$ are shown, with the predicted reversal potential relations for stoichiometries of 2 3 , and 4 (straight lines). Least-squares fit to data (broken line) corresponds to a stoichiometry of $2.8 \pm 0.13$.

positive to the normal resting potential of Müller cells and astrocytes ( -70 to $-90 \mathrm{mV}$; Ransom and Carlini, 1986; Newman, 1988) and suggests that a sustained outward cotransporter flux of $\mathrm{HCO}_{3}^{-}$and $\mathrm{Na}^{+}$occurs at rest.

Voltage-modulated cotransporter fluxes. Neuronal activity within the CNS results in the depolarization of glial cells, a response mediated by a rise in $\left[\mathrm{K}^{+}\right]_{\mathrm{o}}$ (Orkand et al., 1966; Karwoski and Proenza, 1977). Because the $\mathrm{Na}^{+} / \mathrm{HCO}_{3}^{-}$cotransporter is electrogenic, this glial cell depolarization will result in a reduction in the efflux of $\mathrm{HCO}_{3}^{-}$. This reduced efflux should lead to an increase in $\mathrm{pH}_{\mathrm{i}}$.

An increase in $\mathrm{pH}_{\mathrm{i}}$ has, in fact, been observed in glial cells in response to neuronal activity. In rat cortical astrocytes in vivo, there is a strong correlation between activity-induced cell depolarization and an alkaline shift in $\mathrm{pH}$ (Chesler and Kraig, 1989). This alkalinization may be mediated by the $\mathrm{Na}^{+} /$ $\mathrm{HCO}_{3}^{-}$cotransporter.

\section{Functions of the cotransporter}

Internal $\mathrm{pH}$ regulation. In amphibian astrocytes (Astion et al., 1989a), cultured mammalian oligodendrocytes (Kettenmann and Schlue, 1988), and leech glial cells (Deitmer and Schlue, 1989), the cotransporter has been shown to participate in the regulation of $\mathrm{pH}_{\mathrm{i}}$. The cotransporter may serve a similar function in Müller cells.

$\mathrm{CO}_{2}$ regulation. The Müller cell $\mathrm{Na}^{+} / \mathrm{HCO}_{3}^{-}$cotransporter may also help to regulate $\mathrm{CO}_{2}$, and thus $\mathrm{pH}_{\mathrm{o}}$, within the retina. The retinal photoreceptors are one of the most metabolically active cells of the body (particularly in the dark). $\mathrm{CO}_{2}$ generated by these cells must be removed efficiently. $\mathrm{CO}_{2}$ has a high diffusion coefficient and solubility, and most of it may be removed simply by diffusion to choroidal and retinal blood vessels and to the vitreous humor. However, Müller cells may also participate in $\mathrm{CO}_{2}$ regulation. 
Müller cells have high levels of carbonic anhydrase (Musser and Rosen, 1973; Linser et al., 1984), an enzyme that catalyzes the conversion of $\mathrm{CO}_{2}$ and $\mathrm{H}_{2} \mathrm{O}$ to $\mathrm{HCO}_{3}^{-}$and $\mathrm{H}^{+}$(Maren, 1967). Thus, $\mathrm{CO}_{2}$ produced by photoreceptors, which diffuses freely into Müller cells, will be converted into $\mathrm{HCO}_{3}^{-}$and $\mathrm{H}^{+}$within these cells. A rise in $\left[\mathrm{HCO}_{3}^{-}\right]_{\mathrm{i}}$, in turn, would generate an efflux of $\mathrm{HCO}_{3}^{-}$via the cotransporter. Since the cotransporter is localized preferentially to the endfoot of Müller cells, a large fraction of the $\mathrm{HCO}_{3}^{-}$will leave the cell across the endfoot membrane and will be deposited directly into the vitreous humor, which would function as a large $\mathrm{HCO}_{3}^{-}$sink. (Müller cell endfeet lie directly adjacent to the vitreous humor; Newman, 1988.)

In order for Müller cells to remove $\mathrm{CO}_{2}$ from the retina continually, the $\mathrm{H}^{+}$produced in the carbonic anhydrase reaction must also be released from the cell. This would be accomplished most efficiently if the $\mathrm{H}^{+}$were also transferred out of the cell at the endfoot and into the vitreous humor. Thus, this hypothesis of Müller cell regulation of $\mathrm{CO}_{2}$ predicts that an active acid extrusion system, perhaps an $\mathrm{Na}^{+} / \mathrm{H}^{+}$exchanger, is localized to the Müller cell endfoot. $\left(\mathrm{Na}^{+} / \mathrm{H}^{+}\right.$exchangers have been identified in other types of glial cells; Kimelberg et al., 1979; Kettenmann and Schlue, 1988.)

This hypothesis predicts that $\mathrm{pH}$ regulation in the retina would be compromised if carbonic anhydrase activity within Müller cells were blocked. This apparently is the case. When the retina is poisoned with carbonic anhydrase inhibitors, the $\mathrm{pH}$ of the dark-adapted retina drops and light-evoked $\mathrm{pH}$ variations grow larger (Borgula et al., 1989; Oakley and Wen, 1989). Müller cells are implicated in this phenomenon since retinal carbonic anhydrase is localized almost exclusively within Müller cells (Musser and Rosen, 1973).

Regulation of blood flow. Increases in neuronal activity in the cerebral cortex are associated with increased local cerebral blood flow (CBF) (Roy and Sherrington, 1890; Fox and Raichle, 1984), supplying neurons with needed nutrients and oxygen. We have previously suggested that this homeostatic mechanism may be mediated by $\mathrm{K}^{+}$fluxes in astrocytes (Paulson and Newman, 1987). Briefly, increased neuronal activity results in a $\mathrm{K}^{+}$-dependent depolarization of astrocytes. This depolarization generates an efflux of $\mathrm{K}^{+}$from astrocyte endfeet onto the surface of blood vessels, which are completely surrounded by glial endfect. This $\mathrm{K}^{+}$cfflux may lead to a dilation of blood vessels, which are sensitive to $\left[\mathrm{K}^{+}\right]$(McCulloch et al., 1982), and result in an increase in $\mathrm{CBF}$.

The glial cell $\mathrm{Na}^{+} / \mathrm{HCO}_{3}^{-}$cotransport system may also contribute to the regulation of $\mathrm{CBF}$. Astrocytes, as well as Müller cells, possess a Na${ }^{+} / \mathrm{HCO}_{3}^{-}$cotransporter (Astion and Orkand, 1988). As discussed above, glial cell depolarization generated by neuronal activity will result in an influx of $\mathrm{HCO}_{3}^{-}$(or a reduction in its efflux) through the cotransport system. This $\mathrm{HCO}_{3}^{-}$influx may result in glial cell alkalinization (Chesler and Kraig, 1989). Of greater interest, $\mathrm{HCO}_{3}^{-}$influx across astrocyte endfeet may also lead to a rapid acidification of the narrow space between the endfeet and blood vessels. This acidification, in turn, would dilate blood vessels, which are sensitive to interstitial pH (Kuschinsky et al., 1972; Kuschinsky and Wahl, 1978). Arteries on the cortical surface, for instance, display an $18.5 \%$ dilation when the interstitial $\mathrm{pH}$ is shifted from $\mathrm{pH} 7.45$ to 7.2 (McCulloch et al., 1982). In this manner, an activitydependent modulation of the glial cell $\mathrm{Na}^{+} / \mathrm{HCO}_{3}^{-}$cotransporter may regulate $\mathrm{CBF}$. Both $\mathrm{HCO}_{3}^{-}$influx and $\mathrm{K}^{+}$efflux mechanisms in glial cells may work in tandem to regulate blood flow in response to variations in neuronal activity within the brain.

\section{References}

Aronson PS, Bounds SE (1980) Harmaline inhibition of Na-dependent transport in renal microvillus membrane vesicles. Am J Physiol 238: F210-F217.

Astion ML, Orkand RK (1988) Electrogenic $\mathrm{Na}^{+} / \mathrm{HCO}_{3}^{-}$cotransport in neuroglia. Glia 1:355-357.

Astion ML, Chvatal A, Coles JA, Orkand RK (1989a) Intracellular $\mathrm{pH}$ regulation in glial cells of Necturus optic nerve. Acta Physiol Scand 136[S582]:64.

Astion ML, Obaid AL, Orkand RK (1989b) Effects of barium and bicarbonate on glial cells of Necturus optic nerve. Studies with microelectrodes and voltage-sensitive dyes. J Gen Physiol 93:731-744.

Benos DJ (1982) Amiloride: a molecular probe of sodium transport in tissues and cells. Am J Physiol 242:C131-C145.

Borgula GA, Karwoski CJ, Steinberg RH (1989) Light-evoked changes in extracellular pH in frog retina. Vision Res 29:1069-1077.

Boron WF, Boulpaep EL (1983) Intracellular pH regulation in the renal proximal tubule of the salamander. J Gen Physiol 81:53-94.

Boron WF, Boulpaep EL (1989) The electrogenic $\mathrm{Na} / \mathrm{HCO}_{3}$ cotransporter. Kidney Int 36:392-402.

Boron WF, Knakal RC (1989) Intracellular pH-regulating mechanism of the squid axon. Interaction between DNDS and extracellular $\mathrm{Na}^{+}$ and $\mathrm{HCO}_{3}^{-}$. J Gen Physiol 93:123-150.

Brading AF, Aickin CC (1990) Ions, transporters, exchangers and pumps in smooth muscle membranes. Prog Biophys Mol Biol 73: 323-343.

Brew H, Gray PTA, Mobbs P, Attwell D (1986) Endfeet of retinal glial cells have higher densities of ion channels that mediate $\mathrm{K}^{+}$buffering. Nature 324:466-468.

Chesler M, Kraig RP (1989) Intracellular pH transients of mammalian astrocytes. J Neurosci 9:2011-2019.

Cserr HF (1986) The neuronal microenvironment. Ann NY Acad Sci 481:1-393.

Curci S, Debellis L, Fromter E (1987) Evidence for rheogenic sodium bicarbonate cotransport in the basolateral membrane of oxyntic cells of frog gastric fundus. Pfluegers Arch 408:497-504.

Deitmer JW, Schlue WR (1989) An inwardly directed electrogenic sodium-bicarbonate co-transport in leech glial cells. J Physiol (Lond) 411:179-194.

Deitmer JW, Szatkowski M (1990) Membrane potential dependence of intracellular $\mathrm{pH}$ regulation by identified glial cells in the leech central nervous system. J Physiol (Lond) 421:617-631.

Fox PT, Raichle ME (1984) Stimulus rate dependence of regional cerebral blood flow in human striate cortex, demonstrated by positron emission tomography. J Neurophysiol 51:1109-1120.

Gardner-Medwin AR (1983) Analysis of potassium dynamics in mammalian brain tissue. J Physiol (Lond) 335:393-426.

Grassl SM, Aronson PS (1986) $\mathrm{Na}^{+} / \mathrm{HCO}_{3}^{-}$co-transport in basolateral membrane vesicles isolated from rabbit renal cortex. J Biol Chem 261:8778-8783.

Grassl SM, Holohan PD, Ross CR (1987) $\mathrm{HCO}_{3}^{-}$cotransport in basolateral membrane vesicles isolated from rat renal cortex. J Biol Chem 262:2682-2687.

Hamill OP, Marty A, Neher E, Sakmann B, Sigworth FJ (1981) Improved patch-clamp techniques for high-resolution current recording from cells and cell-free membrane patches. Pfluegers Arch 391:85100.

Helbig H, Korbmacher C, Nawrath M, Erb C, Wiederholt M (1989) Sodium bicarbonate cotransport in cultured pigmented ciliary epithelial cells. Curr Eye Res 8:595-598.

Hughes BA, Adorante JS, Miller SS, Lin H (1989) Apical electrogenic $\mathrm{NaHCO}_{3}$ cotransport. A mechanism for $\mathrm{HCO}_{3}$ absorption across the retinal pigment epithelium. J Gen Physiol 94:125-150.

Karwoski CJ, Proenza LM (1977) Relationship between Müller cell responses, a local transretinal potential, and potassium flux. J Neurophysiol 40:244-259.

Karwoski CJ, Lu H-K, Newman EA (1989) Spatial buffering of lightevoked potassium increases by retinal Müller (glial) cells. Science 244 : 578-580.

Kettenmann H, Schlue WR (1988) Intracellular $\mathrm{pH}$ regulation in cultured mouse oligodendrocytes. J Physiol (Lond) 406:147-162. 
Kimelberg HK, Biddlecome S, Bourke RS (1979) SITS-inhibitable Cltransport and $\mathrm{Na}^{+}$-dependent $\mathrm{II}^{+}$production in primary astroglial cultures. Brain Res 173:111-124.

Kuschinsky W, Wahl M (1978) Local chemical and neurogenic regulation of cerebral vascular resistance. Physiol Rev 58:656-689.

Kuschinsky W, Wahl M, Bosse O, Thurau K (1972) Perivascular potassium and $\mathrm{pH}$ as determinants of local pial arterial diameter in cats. A microapplication study. Circ Res 31:240-247.

Langley OK, Ghandour MS, Vincendon G, Gombos G (1980) Carbonic anhydrase: an ultrastructural study in rat cerebellum. Histochem J 12:473-483.

Linser PJ, Sorrentino M, Moscona AA (1984) Cellular compartmentalization of carbonic anhydrase- $C$ and glutamine synthetase in developing and mature mouse neural retina. Dev Brain Res 13:65-71.

Lopes AG, Siebens AW, Giebisch G, Boron WF (1987) Electrogenic $\mathrm{Na} / \mathrm{HCO}_{3}$ cotransport across basolateral membrane of isolated perfused Necturus proximal tubule. Am J Physiol 253:F340-F350.

Maren TH (1967) Carbonic anhydrase: chemistry, physiology, and inhibition. Physiol Rev 47:597-781.

McCulloch J, Edvinsson L, Watt P (1982) Comparison of the effects of potassium and $\mathrm{pH}$ on the calibre of cerebral veins and arteries. Pfluegers. Arch 393:95-98.

Musser GL, Rosen S (1973) Localization of carbonic anhydrase activity in the vertebrate retina. Exp Eye Res 15:105-119.

Newman EA (1984) Regional specialization of retinal glial cell membrane. Nature 309:155-157.

Newman EA (1985a) Membrane physiology of retinal glial (Müller) cells. J Neurosci 5:2225-2239.

Newman EA (1985b) Voltage-dependent calcium and potassium channels in retinal glial cells. Nature 317:809-811.

Newman EA (1987) Distribution of potassium conductance in mammalian Müller (glial) cells: a comparative study. J Neurosci 7:24232432.

Newman EA (1988) Electrophysiology of retinal glial cells. Prog Retinal Res 8:153-171.

Newman EA, Astion ML (1991) Localization and stoichiometry of electrogenic sodium-bicarbonate cotransport in retinal glial cells. Glia $4: 424-428$.

Newman EA, Frambach DA, Odette LL (1984) Control of extracellular potassium levels by retinal glial cell $\mathrm{K}^{+}$siphoning. Science 225:11741175.
Nicholson C (1980) Measurement of extracellular ions in the brain. Trends Neurosci 3:216-218.

Nicholson C, ten Bruggencate G, Stockle H, Steinberg R (1978) Calcium and potassium changes in extracellular microenvironment of cat cerebellar cortex. J Neurophysiol 41:1026-1039.

Oakley B II, Wen R (1989) Extracellular pH in the isolated retina of the toad in darkness and during illumination. J Physiol (Lond) 419: 353-378.

Orkand RK, Nicholls JG, Kuffler SW (1966) Effect of nerve impulses on the membrane potential of glial cells in the central nervous system of amphibia. J Neurophysiol 29:788-806.

Paulson OB, Newman EA (1987) Does the release of potassium from astrocyte endfeet regulate cerebral blood flow? Science 237:896-898.

Ransom BR, Carlini WG (1986) Electrophysiological properties of astrocytes. In: Astrocytes (Federoff S, Vernadakis A, eds), pp 1-49. New York: Academic.

Ritchie JM (1987) Voltage-gated cation and anion channels in mammalian Schwann cells and astrocytes. J Physiol (Paris) 82:248-257.

Roy CS, Sherrington CS (1890) On the regulation of the blood-supply of the brain. J Physiol (Lond) 11:85-108.

Skou JC (1990) The energy coupled exchange of $\mathrm{Na}^{+}$for $\mathrm{K}^{+}$across the cell membrane. The $\mathrm{Na}^{+}, \mathrm{K}^{+}$-pump. FEBS Lett 268:314-324.

Soleimani M, Aronson PS (1989) Ionic mechanism of $\mathrm{Na}^{+}-\mathrm{HCO}_{3}^{-}$ cotransport in rabbit renal basolateral membrane vesicles. J Biol Chem 264:18302-18308.

Soleimani M, Grassl SM, Aronson PS (1987) Stoichiometry of $\mathrm{Na}^{+-}$ $\mathrm{HCO}_{3}^{-}$cotransport in basolateral membrane vesicles isolated from rabbit renal cortex. J Clin Invest 79:1276-1280.

Sykova E, Svoboda J (1990) Extracellular alkaline-acid-alkaline transients in the rat spinal cord evoked by peripheral stimulation. Brain Res 512:181-189.

Urbanics R, Leniger-Follert E, Lubbers DW (1978) Time course of changes of extracellular $\mathrm{H}^{+}$and $\mathrm{K}^{+}$activities during and after direct electrical stimulation of the brain cortex. Pfluegers Arch 378:47-53.

Wiederholt M, Jentsch TJ, Keller SK (1985) Electrogenic sodiumbicarbonate symport in cultured corneal endothelial cells. Pfluegers Arch 405:S167-S171.

Yoshitomi K, Burckhardt B-C, Fromter E (1985) Rheogenic sodiumbicarbonate cotransport in the peritubular cell membrane of rat renal proximal tubule. Pfluegers Arch 405:360-366. 